\title{
ANN Modeling For Forecasting of VCR Engine Performance And Emission Parameters Fuelled With Green Diesel Extracted From Waste Biomass Resources
}

\section{Rajayokkiam Manimaran ( $\nabla$ manimaran@mech.sastra.edu )}

SASTRA Deemed University: Shanmugha Arts Science Technology and Research Academy https://orcid.org/0000-0002-9157-5058

\section{Thangavel Mohanraj}

SASTRA Deemed University: Shanmugha Arts Science Technology and Research Academy Moorthy Venkatesan

SASTRA Deemed University: Shanmugha Arts Science Technology and Research Academy

\section{Research Article}

Keywords: Green diesel, VCR engine, Performance, Emission, Artificial neural network

Posted Date: July 29th, 2021

DOl: https://doi.org/10.21203/rs.3.rs-675366/v1

License: (c) (1) This work is licensed under a Creative Commons Attribution 4.0 International License. Read Full License

Version of Record: A version of this preprint was published at Environmental Science and Pollution Research on March 10th, 2022. See the published version at https://doi.org/10.1007/s11356-022-195008. 


\section{Abstract}

In this research work, the experimental tests were conducted on a single-cylinder, constant speed, variable compression ratio (VCR) engine fuelled with green diesel extracted from waste trichosanthes cucumerina seeds. The engine test blends are prepared with different trichosanthes cucumerina biodiesel (TCB) proportions of $30 \%, 50 \%$ and $70 \%$ in diesel fuel, and their thermo-physical properties were assessed as per the ASTM standards. At full load condition, the TCB30 blend operated at the CR 18:1 gives better engine performance and reduced emission levels of $\mathrm{HC}$ by $13.51 \%$, CO by $10.82 \%$ and smoke opacity by $16.87 \%$, equated with neat diesel fuel. With the support of experimental results, the performance (BTE, BSFC and EGT) and emission parameters $\left(\mathrm{HC}, \mathrm{CO}, \mathrm{NO}_{x}\right.$, smoke opacity and $\left.\mathrm{CO}_{2}\right)$ are predicted using multiple regression artificial neural network (ANN) model. This trained ANN model results in an average correlation coefficient $\left(R^{2}\right)$ value is 0.9967 , which is closer to 1 . It indicates that the proposed ANN model can generate the exact correlation between input factors and output responses.

\section{Introduction}

The diesel engines are the prime movers for power machinery, automotive applications and the agriculture sector to produce high torque with better fuel efficiency than petrol engines (Mohan et al. 2014). But, it suffers from the emissions of smoke, carbon dioxide $\left(\mathrm{CO}_{2}\right)$, and oxides of nitrogen $\left(\mathrm{NO}_{\mathrm{x}}\right)$ promotes environmental pollution, global warming and ozone layer depletion (Elsanusi et al. 2017). Majorly the increase in emissions in diesel engines caused by the usage of fossil fuels. Nowadays, researchers are focus on the alternative energy source of biodiesel production from waste biomass (Balasubramanian et al. 2018). Biodiesel is the best solution for replacing fossil fuel, and its fuel properties comparable to neat diesel fuel (Ashok et al. 2019). It can be extracted from waste biomass resources as an attractive technique. These extracted biodiesel physicochemical properties are similar to diesel fuel allowed to operate the engine without modification. Usage of biodiesel minimizes $\mathrm{CO}_{2}$, unburned HC, smoke and sulfur emissions during engine operations (Subramani et al. 2020). In the past decades, a lot of research work was done on different biodiesels in diesel engines and their performance and emission parameters were investigated (Vigneswaran et al. 2018).

The computer-based learning techniques are more valuable to estimate the diesel engine operating characteristics (Işcan 2020). Currently, researchers have switched to approaches that can do the same since the experimental tests on engine parameters are very time-consuming and more expensive (Mehra et al., 2018). The ANN model is widely used for various automotive applications and diminish the number of live experiments. It can solve non-linear problems with high precision, which suits the prediction of engine process parameters (Yang et al., 2018). Some researchers were used the ANN modeling to explore engine operating variables effect on the desired output responses. Aydın et al. (2020) varying the input factors of engine load and injection pressure with different biodiesel-diesel blends. Engine performance and emission characteristics were predicted using the experimental results. ANN model revealed that the $\mathrm{R}^{2}$ value range from 0.8663 to 0.9858 for perfect prediction. It was concluded that ANN models are more 
significant for forecasting the engine process parameters. Krishnamoorthi et al. (2019) investigated the combustion, performance and emission parameters of different ternary fuel blends in a VCR engine. The input factors of compression ratio, engine speed and power output are taken for optimization. ANN model predicted $\mathrm{R}^{2}$ values lie between 0.910 to 0.999 , and it shows that the accuracy of the predicted value correlates with the experimental value. Overall, it was concluded that using the ANN model plays a vital role in increasing engine performance and reducing tailpipe emissions. Hosseini et al. (2020) analyzed the engine process parameters using B5 and B10 blends mixed with alumina nano-catalyst at different proportions. R values of the ANN model are $0.9999,0.9994$ and 0.9995 for training, validation and testing, respectively. It indicates the accuracy of the proposed ANN model correlated with experimental results. Based on the results, the ANN model is a powerful tool to predict performance and emission parameters in the $\mathrm{Cl}$ engine.

Babu et al. (2020) developed the ANN model for forecasting CRDi assisted diesel engine parameters. The experiments were conducted for fixed pre-injection at $30^{\circ} \mathrm{CA}$ before TDC, varied the primary injection timing from $15^{\circ} \mathrm{CA}$ to $21^{\circ} \mathrm{CA}$ before TDC and post-injection happen at $6^{\circ} \mathrm{CA}$ before TDC to $6^{\circ} \mathrm{CA}$ after TDC correspondingly. It shows that the minimum emission levels and maximum engine performance at advanced injection timing. ANN models gave lower RMSE ( 0.01 to 0.02$)$, and $\mathrm{R}$ values ranged from 0.980 to 0.998 , respectively. It was established the ANN model is more preferred than that of theoretical and empirical models due to their higher accuracy in predicting the output responses. Sevinc et al. (2020) designed the ANN model to predict the 2-Ethylhexyl nitrate (EHN)-diesel fuel operated thermal barrier coated engine emission parameters. In the experimental investigation, the EHN was blended with diesel at $3 \%, 6 \%$ and $9 \%$ volume fractions and shows that a significant reduction in $\mathrm{NO}_{\mathrm{x}}$ and smoke emissions. The engine speed $(n)$ was taken as an input factor, and corresponding output responses are $\mathrm{HC}, \mathrm{CO}, \mathrm{NO}_{\mathrm{x}}$ and smoke density in the ANN modeling. $\mathrm{R}$ values for $\mathrm{HC}, \mathrm{CO}, \mathrm{NO}_{x}$ and smoke density are $0.9913,0.9939$, 0.9976 and 0.9974 , which is closer to 1 , indicates the high accuracy rate of ANN prediction. Table 1 shows the literature summary on forecasting engine performance and emissions parameters fuelled with different biodiesel blends using the ANN model by some researchers. 
Table 1

Summary of literature on forecasting of engine performance and emissions parameters using biodiesel blends

\begin{tabular}{|c|c|c|c|c|c|c|}
\hline Reference & $\begin{array}{l}\text { Engine } \\
\text { design }\end{array}$ & Fuel used & $\begin{array}{l}\text { Model } \\
\text { used }\end{array}$ & $\begin{array}{l}\text { Input } \\
\text { parameters }\end{array}$ & $\begin{array}{l}\text { Output } \\
\text { parameters }\end{array}$ & $R$ value \\
\hline $\begin{array}{l}\text { Karthic et al. } \\
\text { (2020) }\end{array}$ & $\begin{array}{l}\text { Single } \\
\text { cylinder, four } \\
\text { stroke, water } \\
\text { cooled, } \\
\text { Kirloskar AV- } \\
1 \text { model } \\
\text { diesel } \\
\text { engine }\end{array}$ & $\begin{array}{l}\text { Diesel, } \\
\text { Mahua oil } \\
\text { and Mahua } \\
\text { oil-hydrogen } \\
\text { blend }\left(\mathrm{H}_{2}\right)\end{array}$ & $\begin{array}{l}\text { ANN } \\
\text { model }\end{array}$ & $\begin{array}{l}\text { Engine } \\
\text { load, high } \\
\text { octane fuel } \\
\text { flow rate, } \\
\text { fuel } \\
\text { injection } \\
\text { pressure } \\
\text { and fuel } \\
\text { injection } \\
\text { timing }\end{array}$ & $\begin{array}{l}\text { BTE, EGT, } \\
\text { HC, CO, NO } \\
\text { and Smoke }\end{array}$ & $\begin{array}{l}\text { BTE = } \\
0.9981, \\
\text { EGT = } \\
0.9994, \\
\text { HC = } \\
0.9957, \\
\text { CO = } \\
0.9989, \\
\text { NO = } \\
0.9993 \\
\text { and } \\
\text { Smoke }= \\
0.9920\end{array}$ \\
\hline $\begin{array}{l}\text { Uslu et al. } \\
\text { (2018) }\end{array}$ & $\begin{array}{l}\text { Single- } \\
\text { cylinder, four } \\
\text { stroke, air- } \\
\text { cooled } \\
\text { direct- } \\
\text { injection } \\
\text { diesel } \\
\text { engine }\end{array}$ & $\begin{array}{l}\text { Pure diesel } \\
\text { and diesel- } \\
\text { DEE (diethyl } \\
\text { ether) fuel } \\
\text { mixtures }\end{array}$ & $\begin{array}{l}\text { ANN } \\
\text { model }\end{array}$ & $\begin{array}{l}\text { Engine } \\
\text { load, } \\
\text { engine } \\
\text { speed and } \\
\text { fuel } \\
\text { blending } \\
\text { ratio }\end{array}$ & 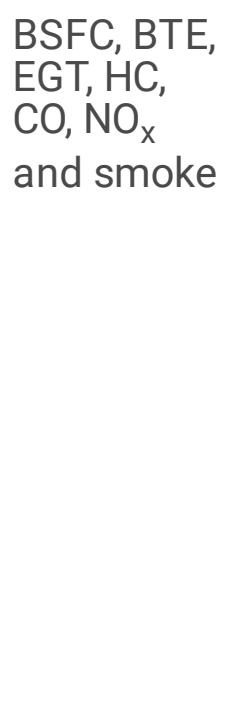 & $\begin{array}{l}\mathrm{BSFC}= \\
0.985, \\
\mathrm{BTE}= \\
0.9829, \\
\mathrm{EGT}= \\
0.9878, \\
\mathrm{HC}= \\
0.964, \\
\mathrm{CO}= \\
0.9825, \\
\mathrm{NO}= \\
0.9831 \\
\text { and } \\
\text { Smoke }= \\
0.9796\end{array}$ \\
\hline $\begin{array}{l}\text { Dey et al. } \\
(2020)\end{array}$ & $\begin{array}{l}\text { Single } \\
\text { cylinder, four } \\
\text { stroke, VCR, } \\
\text { water } \\
\text { cooled, } \\
\text { vertical } \\
\text { direct } \\
\text { injection } \\
\text { diesel } \\
\text { engine }\end{array}$ & $\begin{array}{l}\text { Diesel-palm } \\
\text { biodiesel- } \\
\text { ethanol } \\
\text { blends }\end{array}$ & $\begin{array}{l}\text { ANN } \\
\text { model - } \\
\text { Fuzzy } \\
\text { approach }\end{array}$ & $\begin{array}{l}\text { Engine } \\
\text { load, } \\
\text { percentage } \\
\text { of diesel } \\
\text { fuel, } \\
\text { percentage } \\
\text { of palm } \\
\text { biodiesel } \\
\text { and } \\
\text { percentage } \\
\text { of ethanol }\end{array}$ & $\begin{array}{l}\mathrm{BSEC}, \mathrm{UHC}, \\
\mathrm{NO}_{x} \text { and } \\
\mathrm{CO}_{2}\end{array}$ & $\begin{array}{l}\mathrm{BSEC}= \\
0.9986, \\
\mathrm{UHC}= \\
0.9932, \\
\mathrm{NO}_{\mathrm{x}}= \\
0.9987 \\
\text { and } \mathrm{CO}_{2} \\
=0.9975\end{array}$ \\
\hline
\end{tabular}




\begin{tabular}{|c|c|c|c|c|c|c|}
\hline Reference & $\begin{array}{l}\text { Engine } \\
\text { design }\end{array}$ & Fuel used & $\begin{array}{l}\text { Model } \\
\text { used }\end{array}$ & $\begin{array}{l}\text { Input } \\
\text { parameters }\end{array}$ & $\begin{array}{l}\text { Output } \\
\text { parameters }\end{array}$ & $R$ value \\
\hline $\begin{array}{l}\text { Dharma et } \\
\text { al. (2017) }\end{array}$ & $\begin{array}{l}\text { Single } \\
\text { cylinder, } \\
\text { water } \\
\text { cooled, TF } \\
120 \mathrm{M} \\
\text { Yanmar } \\
\text { diesel } \\
\text { engine }\end{array}$ & $\begin{array}{l}\text { Jatropha } \\
\text { curcas-Ceiba } \\
\text { pentandra } \\
\text { biodiesel- } \\
\text { diesel blends }\end{array}$ & $\begin{array}{l}\text { ANN } \\
\text { model }\end{array}$ & $\begin{array}{l}\text { Engine } \\
\text { speed and } \\
\text { biodiesel } \\
\text { blends }\end{array}$ & $\begin{array}{l}\mathrm{BSFC}, \\
\text { Engine } \\
\text { torque, } \\
\text { Brake } \\
\text { power, EGT, } \\
\mathrm{BTE}, \mathrm{CO}, \\
\mathrm{CO}_{2}, \mathrm{NO}_{\mathrm{x}} \\
\text { and smoke } \\
\text { opacity }\end{array}$ & $\begin{array}{l}\mathrm{BSFC}= \\
0.997, \\
\text { Engine } \\
\text { torque = } \\
0.997, \\
\text { Brake } \\
\text { power = } \\
0.991 \text {, } \\
\text { EGT= } \\
0.995 \text {, } \\
\mathrm{BTE}= \\
0.991, \\
\mathrm{CO}= \\
0.997, \\
\mathrm{CO}_{2}= \\
0.997, \\
\mathrm{NO}_{\mathrm{x}}= \\
0.997 \\
\text { and } \\
\text { Smoke } \\
\text { opacity = } \\
0.996\end{array}$ \\
\hline $\begin{array}{l}\text { Ghobadian } \\
\text { et al. (2009) }\end{array}$ & $\begin{array}{l}\text { Two } \\
\text { cylinder, } \\
\text { four-stroke, } \\
\text { air cooled, } \\
\text { RD270 } \\
\text { Ruggerini } \\
\text { diesel } \\
\text { engine }\end{array}$ & $\begin{array}{l}\text { Waste } \\
\text { vegetable } \\
\text { cooking } \\
\text { biodiesel and } \\
\text { diesel fuel } \\
\text { blends }\end{array}$ & $\begin{array}{l}\text { ANN } \\
\text { model }\end{array}$ & $\begin{array}{l}\text { Engine } \\
\text { speed and } \\
\text { biofuel } \\
\text { blend }\end{array}$ & $\begin{array}{l}\text { Engine } \\
\text { torque, } \\
\text { SFC, CO } \\
\text { and HC }\end{array}$ & $\begin{array}{l}\text { Engine } \\
\text { torque }= \\
0.9487, \\
\text { SFC = } \\
0.999, \\
\mathrm{CO}= \\
0.929 \\
\text { and } \mathrm{HC}= \\
0.999\end{array}$ \\
\hline $\begin{array}{l}\text { Ramalingam } \\
\text { et al. (2020) }\end{array}$ & $\begin{array}{l}\text { Single- } \\
\text { cylinder, } \\
\text { four-stroke, } \\
\text { water } \\
\text { cooled, } \\
\text { direct } \\
\text { injection } \\
\text { diesel } \\
\text { engine }\end{array}$ & $\begin{array}{l}\text { Citronella } \\
\text { and } \\
\text { Cymbopogon } \\
\text { flexuous } \\
\text { biofuel-diesel } \\
\text { blends }\end{array}$ & $\begin{array}{l}\text { ANN } \\
\text { model }\end{array}$ & $\begin{array}{l}\text { Brake } \\
\text { power and } \\
\text { fuel blends }\end{array}$ & $\begin{array}{l}\mathrm{BTE}, \mathrm{BSEC}, \\
\mathrm{CO}, \mathrm{CO}_{2} \\
\mathrm{HC}, \mathrm{NO}_{\mathrm{x}} \\
\text { and smoke }\end{array}$ & $\begin{array}{l}\mathrm{BTE}= \\
0.9965, \\
\mathrm{BSEC}= \\
0.989, \\
\mathrm{CO}= \\
0.9784, \\
\mathrm{CO}_{2}= \\
0.955, \\
\mathrm{HC}= \\
0.9076, \\
\mathrm{NO}_{\mathrm{x}}= \\
0.9849 \\
\text { and } \\
\text { smoke }= \\
0.993\end{array}$ \\
\hline
\end{tabular}




\begin{tabular}{|c|c|c|c|c|c|c|}
\hline Reference & $\begin{array}{l}\text { Engine } \\
\text { design }\end{array}$ & Fuel used & $\begin{array}{l}\text { Model } \\
\text { used }\end{array}$ & $\begin{array}{l}\text { Input } \\
\text { parameters }\end{array}$ & $\begin{array}{l}\text { Output } \\
\text { parameters }\end{array}$ & $R$ value \\
\hline $\begin{array}{l}\text { Karthickeyan } \\
\text { et al. (2017) }\end{array}$ & $\begin{array}{l}\text { Single } \\
\text { cylinder, } \\
\text { Four stroke, } \\
\text { water } \\
\text { cooled, } \\
\text { Kirloskar TV } \\
1 \text { model, } \\
\text { compression } \\
\text { ignition } \\
\text { engine }\end{array}$ & $\begin{array}{l}\text { Orange oil } \\
\text { methyl ester } \\
\text { (OME)-diesel } \\
\text { blends }\end{array}$ & $\begin{array}{l}\text { ANN } \\
\text { model }\end{array}$ & $\begin{array}{l}\text { Engine } \\
\text { load, Fuel } \\
\text { blend and } \\
\text { CR }\end{array}$ & $\begin{array}{l}\mathrm{BTE}, \mathrm{BSFC}, \\
\mathrm{CO}, \mathrm{NO}_{\mathrm{x}} \\
\text { and } \mathrm{HC}^{-}\end{array}$ & $\begin{array}{l}\mathrm{BTE}= \\
0.998, \\
\mathrm{BSFC}= \\
0.9999, \\
\mathrm{CO}= \\
0.993 \\
\mathrm{NO}_{\mathrm{x}}= \\
0.997 \\
\text { and } \mathrm{HC}= \\
0.9682\end{array}$ \\
\hline
\end{tabular}

Numerous research studies have been conducted on different biodiesel blends in the VCR engine. Only the minimum research works were reported from the literature to predict engine performance and emission parameters. Initially, the trichosanthes cucumerina bio-oil (TCO) was extracted from the waste biomass of trichosanthes cucumerina seed using soxhlet apparatus. TCO fuel properties were analyzed using ASTM and AOAC standards. It shows that the higher kinematic viscosity and density and lower heating value compared with neat diesel fuel. Usage of neat TCO for engine operation leads to fuel pumping and atomization problem, gum formation, thermal cracking, carbon deposit over injection nozzle tips and smoke emission (Ramalingam et al. 2020). The above problems are sorted out with the production of biodiesel from TCO using the trans-esterification process. After that, the produced TCB blended with BDF at different concentrations, namely TCB30, TCB50, TCB70 and TCB100. The present research work is conducted on a single-cylinder VCR engine fuelled with BDF and TCB blends. The results are taken for different loading $(\mathrm{L})$ conditions and compression ratios (CR). Next, the ANN model was trained with experimental data to forecast the diesel engine performance (BTE, BSFC and EGT) and emission $\left(\mathrm{HC}, \mathrm{CO}, \mathrm{NO}_{x}\right.$, Smoke opacity and $\left.\mathrm{CO}_{2}\right)$ parameters.

\section{Materials And Methods}

\section{TCO extraction process}

The trichosanthes cucumerina bio-oil (TCO) is extracted from waste seeds of trichosanthes cucumerina fruit. The waste seeds are collected from the green market and horticulture free of charge in this bio-oil extraction process. Initially, the collected waste seeds were dried at a specific temperature of $65^{\circ} \mathrm{C}$ to remove the moisture content, and it has been converted into powder. These powered seeds are packed in a satin cloth and placed inside the thimble of the soxhlet. The extractor of hexane is used as a solvent to extract the bio-oil in the Soxhlet apparatus, as shown in Fig. 1. It extracted $28.4 \pm 0.4 \%$ of TCO yield, and their free fatty acid content (FFA) are measured through GC-MS analysis.

\section{GC-MS analysis for TCO}


The GC-MS (Gas Chromatography-Mass Spectroscopy) analysis was performed to investigate the various chemical constitutes present in the TCO. Figure 2 shows that the extracted TCO comprises higher percentage of oleic acid $\left(\mathrm{C}_{18} \mathrm{H}_{34} \mathrm{O}_{2}\right)$, dodecanoic acid $\left(\mathrm{C}_{12} \mathrm{H}_{24} \mathrm{O}_{2}\right)$, n-Hexadecanoic acid $\left(\mathrm{C}_{16} \mathrm{H}_{32} \mathrm{O}_{2}\right)$ and Octadecanoic acid $\left(\mathrm{C}_{18} \mathrm{H}_{36} \mathrm{O}_{2}\right)$. The oleic acid $\left(\mathrm{C}_{18} \mathrm{H}_{34} \mathrm{O}_{2}\right)$ with a peak area of $43.27 \%$ was observed as the highest one in total FFA. Table 2 shows the list of FFA present in the TCO. Also, it founds the chemical formula for TCO is $\mathrm{C}_{16} \mathrm{H}_{30} \mathrm{O}_{2}$; the molecular weight is $252.5 \mathrm{~g} / \mathrm{mol}$ and dark brownish colour. Hence, the extracted TCO is converted into green diesel through a technique of the trans-esterification process.

Table 2. Chemical compounds present in TCO 


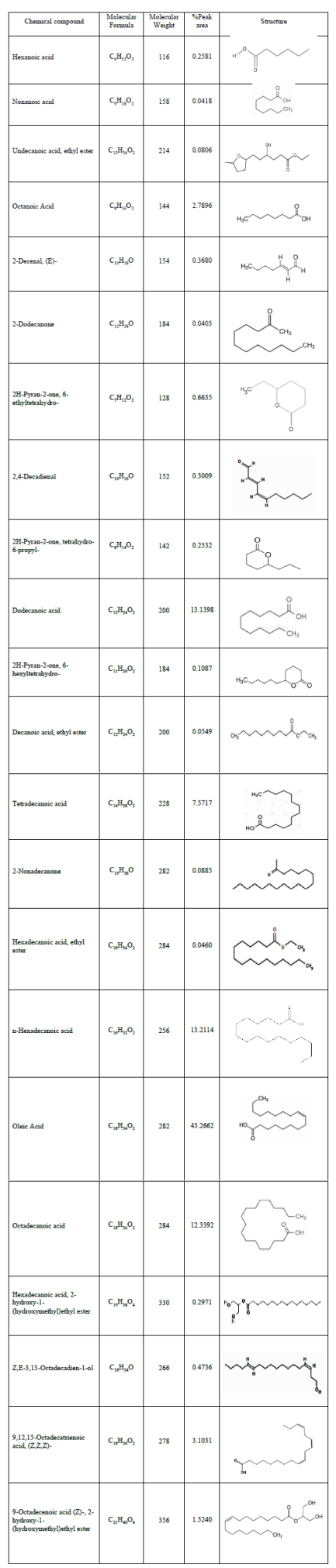

\section{Green diesel (TCB) production}

In this process, the extracted TCO was converted into trichosanthes cucumerina biodiesel (TCB) as named as green diesel through acid and alkali catalyst, and the overall TCB production process is represented in Fig. 3. Initially, the part of FFA content available in the TCO is removed using acid catalyst 
$1 \mathrm{wt} \%$ of $\mathrm{H}_{2} \mathrm{SO}_{4}$ and added with the mixture of $\mathrm{TCO}+\mathrm{CH}_{3} \mathrm{OH}$ heated at the reaction temperature of $60^{\circ} \mathrm{C}$ for 45 minutes to produce the ester. Now, the acid value of esterified TCO is $0.74 \mathrm{mg} \mathrm{KOH} / \mathrm{mg}$.

Next, the esterified TCO can be converted into TCB with an alkali catalyst in the transesterification process. The sodium methoxide solution was prepared by mixing $250 \mathrm{ml} \mathrm{of} \mathrm{CH}_{3} \mathrm{OH}$ and $3.5 \mathrm{~g}$ of sodium hydroxide in a conical flask. Correspondingly, 1 litre of esterified TCO was taken into the breaker and heated up to $60^{\circ} \mathrm{C}$ temperature for 30 minutes. The heated TCO is poured into a separate container added with sodium methoxide solution to form a mixture. It is allowed to settle for 2 hours, and the two distinct layers are formed. The ester is formed along with glycerin, deposited at the bottom. It can be eliminated from the ester by a separation process.

Finally, the traces amount of methanol $\left(\mathrm{CH}_{3} \mathrm{OH}\right)$ and water $\left(\mathrm{H}_{2} \mathrm{O}\right)$ present in the green diesel was removed while heating beyond $75^{\circ} \mathrm{C}$ temperature. In this purification process, pure TCB produced, and the yield is about $92.7 \pm 0.4 \%$. It is blended with neat diesel fuel on a volume basis of $30 \%, 50 \%$ and $70 \%$ respectively and used for experimental analysis. The thermophysical properties of neat diesel fuel and green diesel (TCB) blends were analyzed using ASTM standards and mentioned in Table 3.

Table 3

Thermo-physical properties of Diesel, TCO and TCB blends

\begin{tabular}{|lccccccc|}
\hline Fuel Properties & Diesel & TCO & TCB30 & TCB50 & TCB70 & TCB100 & $\begin{array}{l}\text { Standard } \\
\text { methods }\end{array}$ \\
\hline $\begin{array}{l}\text { Kinematic viscosity at } 40^{\circ} \mathrm{C} \\
(\mathrm{cSt})\end{array}$ & 2.71 & 42.85 & 3.01 & 3.51 & 3.64 & 4.26 & $\begin{array}{l}\text { ASTM D } \\
445\end{array}$ \\
\hline Density at $15^{\circ} \mathrm{C}\left(\mathrm{kg} / \mathrm{m}^{3}\right)$ & 836 & 912 & 841 & 848 & 852 & 856 & $\begin{array}{l}\text { ASTM D } \\
1298\end{array}$ \\
\hline Heating value $(\mathrm{MJ} / \mathrm{kg})$ & 42.5 & 32.45 & 41.7 & 40.52 & 39.83 & 38.50 & $\begin{array}{l}\text { ASTM D } \\
240\end{array}$ \\
\hline Cetane number $(\mathrm{CN})$ & 51 & 35 & 50 & 47 & 45 & 44 & $\begin{array}{l}\text { ASTM D } \\
976\end{array}$ \\
\hline Flash Point $\left({ }^{\circ} \mathrm{C}\right)$ & 68 & 236 & 84 & 112 & 135 & 158 & $\begin{array}{l}\text { ASTM D } \\
93\end{array}$ \\
\hline Fire Point $\left({ }^{\circ} \mathrm{C}\right)$ & 86 & 262 & 103 & 126 & 147 & 169 & $\begin{array}{l}\text { ASTM D } \\
93\end{array}$ \\
\hline
\end{tabular}

\section{TGA analysis for TCB}

Thermogravimetric analysis (TGA) ensures the thermal stability, volatilization and decomposition of TCB fuel mass were characterized by the TG and DTG curves (Thiruvenkatachari et al. 2021). Figure 4 indicates the measure of the TGA index for the decrease in weight percentage with increasing temperature. The weight loss is observed in the green diesel (TCB), ranging from $200^{\circ} \mathrm{C}$ to $300^{\circ} \mathrm{C}$. It is due 
to the oxidation of organic phases and dehydration of TCB fuel. The DTG curve shows that the TCB peaks occur at the temperature of $264.67^{\circ} \mathrm{C}$. From the DTG peaks, the TCB fuel stability was observed in the temperature ranges between $250^{\circ} \mathrm{C}$ to $300^{\circ} \mathrm{C}$.

\section{Engine experimental setup}

The effect of neat diesel and TCB blends on engine operating variables are tested in a single-cylinder, constant speed, water-cooled and four-stroke Kirloskar TV1 model $\mathrm{Cl}$ engine. The experimental tests were conducted at five different engine loading conditions ( 0 kW, $1.3 \mathrm{~kW}, 2.6 \mathrm{~kW}, 3.9 \mathrm{~kW}$ and $5.2 \mathrm{~kW})$ applied through an eddy current dynamometer tested with six fuel blends (Neat diesel, TCB30, TCB50, TCB70, and TCB100). A fixed variable compression ratio engine was selected for this experimental analysis. All the test readings are taken for different compression ratios varied from 16:1 to 18:1 by tilting the cylinder head using Allen bolts. The position of the cylinder head adjusted by the CR adjuster to vary the clearance volume. The $\mathrm{CR}$ indicator indicates the variation of compression ratio. A crank angle encoder and pressure transducer are fitted in the test engine to capture the engine combustion data using the data acquisition system (DAS). However, the EGT is measured using a K-type thermocouple fixed in the engine tailpipe. Exhaust emissions of $\mathrm{HC}, \mathrm{CO}, \mathrm{CO}_{2}$ and $\mathrm{NO}_{\mathrm{x}}$, are measured using $\mathrm{AVL}$ DI gas $444 \mathrm{~N}$ five gas analyzer. Correspondingly, the smoke emission is measured by an AVL 437C type smoke meter. During the experimental investigation, the test readings are repeated three times for each fuel blends to achieve a measurement accuracy, and their mean values are taken for further studies. The technical engine specifications are mentioned in Table 4, and the experimental setup is presented in Fig. 5, respectively. These experimental results act as a source file for ANN application. Percentage uncertainties of different operating parameters like brake power (BP), engine speed (n), BSFC, BTE, EGT, $\mathrm{HC}, \mathrm{CO}, \mathrm{NO}_{\mathrm{x}}$, smoke opacity and $\mathrm{CO}_{2}$ were measured using the square root method by Eq. (1).

$$
\begin{aligned}
& =\sqrt{(\mathrm{BP})^{2}+(\mathrm{n})^{2}+(\mathrm{BSFC})^{2}+(\mathrm{BTE})^{2}+(\mathrm{EGT})^{2}+(\mathrm{HC})^{2}+(\mathrm{CO})^{2}+(\mathrm{NOx})^{2}+(\text { Smoke })^{2}+\left(\mathrm{CO}_{2}\right)^{2}} \\
& =\sqrt{(0.1)^{2}+(0.5)^{2}+(0.8)^{2}+(1.32)^{2}+(0.2)^{2}+(1.5)^{2}+(0.7)^{2}+(1)^{2}+(1)^{2}+(0.2)^{2}}
\end{aligned}
$$

Table 4. Engine technical specifications 


\begin{tabular}{|ll|}
\hline Engine Make and Model & Kirloskar TV1 \\
\hline Type & $\begin{array}{l}\text { Single cylinder, 4-stroke, water cooled, direct injection, variable } \\
\text { compression ratio, diesel engine }\end{array}$ \\
\hline Bore $(\mathrm{B}) \times$ Stroke (L) & $87.5 \mathrm{~mm} \times 110 \mathrm{~mm}$ \\
$\begin{array}{l}\text { Compression ratio (CR) } \\
\text { range }\end{array}$ & $16: 1$ to $18: 1$ \\
\hline Rated power output & $5.2 \mathrm{~kW}$ at $1500 \mathrm{rpm}$ \\
\hline $\begin{array}{l}\text { Engine displacement } \\
\text { volume }\end{array}$ & $661 \mathrm{cc}$ \\
\hline $\begin{array}{l}\text { Fuel injector opening } \\
\text { pressure (FIP) }\end{array}$ & $20 \mathrm{Mpa}$ \\
\hline $\begin{array}{l}\text { Fuel injection timing (FIT) } \\
\text { Connecting rod length }(I)\end{array}$ & 234 mm $\mathrm{bTDC}$ \\
\hline $\begin{array}{l}\text { Combustion chamber } \\
\text { design }\end{array}$ & Hemispherical type \\
\hline $\begin{array}{l}\text { Fuel injector nozzle hole } \\
\text { and diameter }\end{array}$ & 3 holes and $0.3 \mathrm{~mm}$ \\
\hline
\end{tabular}

The combined uncertainty of the experimental test is $\pm 2.731 \%$

\section{Results And Discussion \\ Experimental analysis \\ Brake thermal efficiency (BTE)}

Figure 6 exemplifies the variation of BTE with BP for CR 16:1, CR 17:1 and CR 18:1. The effective burning of test fuels inside the combustion chamber and conversion of useful BP output is named the BTE (Dhinesh et al., 2016). The figure shows that the increase in engine load (L) and CR increases the BTE gradually for all test fuels. However, the neat TCB and its blends follow the decrease in trend for all loading conditions. The TCB blends with lower heating value and higher kinematic viscosity and density promote inferior atomization and vaporization, leading to lesser BTE (Ashok et al. 2018). Among the different TCB blends, the TCB30 blend shows improved BTE for all CR and engine load variations because the lower viscosity and density of the TCB30 mixture makes the fuel combustion as efficient (Baranitharan et al. 2019). At top load condition, the CR 18:1 shows that the maximum BTE for TCB30 blend (33.52\%) is highest among other TCB blends and is $1.25 \%$ less than that of neat diesel fuel. Generally, the TCB blends are combusted at higher CR 18:1, resulting in increased compression pressure and the temperature to shorten the ignition delay period (ID) and enhance the test fuel volatility 
promoting higher BTE (Wamankar et al. 2015). But, the CR 16:1 and 17:1 result in lower BTE for all test fuels.

\section{Brake specific fuel consumption (BSFC)}

BSFC measures test fuel efficiency and the ratio of total fuel consumption (TFC) to engine BP output (Nanthagopal et al., 2019). An interaction between TCB blend, CR and BP on the BSFC is shown in Fig. 7. It indicates the variation of CR from 16:1 to 18:1 decreases the BSFC for an increase in BP. But, the rise in TCB blend ratio on neat diesel fuel shows more BSFC for full power outputs due to the decreasing trend of green diesel heating value resulted in higher BSFC (Venugopal et al. 2018). Furthermore, the CR varied from 16:1 to 18:1 decreases the ignition delay (ID) period for all operated test fuels makes the highest decrement in BSFC (Hosamani et al. 2018). For higher CR 18:1 shows that the minimum BSFC was observed as $0.264 \mathrm{~kg} / \mathrm{kWh}$ for diesel, $0.27 \mathrm{~kg} / \mathrm{kWh}$ for TCB30, $0.287 \mathrm{~kg} / \mathrm{kWh}$ for TCB50, $0.311 \mathrm{~kg} / \mathrm{kWh}$ for TCB70 and $0.326 \mathrm{~kg} / \mathrm{kWh}$ for TCB100 operated at peak power outputs. The high mean effective pressure developed inside the combustion chamber promotes the combustion as complete for all test fuels resulting in the efficient power output at minimum BSFC (Lahane and Subramanian 2014). But these BSFC values are maximum at lower CR of 16:1 and 17:1. Because inadequate mixing and atomization of test blends caused incomplete combustion, leading to higher BSFC (Vellaiyan 2020).

\section{Exhaust gas temperature (EGT)}

Figure 8 shows the variation of EGT with brake power operated at CR 16:1, CR 17:1 and CR 18:1. It was observed that the increase in BP shows an increasing trend of EGT for all the test fuels. Similarly, the higher CR 18:1 generates more EGT since the engine operating temperature is high (Shivakumar et al., 2011). EGT for green diesel is more when correlated with neat diesel fuel, and it increases as the proportion of TCB is increased. It may be credited due to higher physical ID period, increased viscosity and poor volatility of TCB blend (Senthil Kumar et al. 2019). At top load engine operation, the value of EGT for TCB100 is $382.48{ }^{\circ} \mathrm{C}, 394.23^{\circ} \mathrm{C}$ and $411.23^{\circ} \mathrm{C}$ operated at the CR 16:1, CR 17:1 and CR 18:1, respectively. This may occur because more oxygen content (O2) in the TCB100 promotes higher EGT (Dhinesh et al., 2016). The engine operated at higher CR 18:1 compress the air is entered into the cylinder increases the temperature. It helps to better fuel mixing, and atomization leads to complete combustion that lowers the EGT for neat diesel fuel (Wamankar et al., 2015).

\section{Hydrocarbon emission ( $\mathrm{HC})$}

Figure 9 portrays the variation of $\mathrm{HC}$ emission with the influence of different compression ratios (CR 16:1, CR 17:1 and CR 18:1) operated at low load and full load conditions. Generally, the unburned HC emission is formed during rich mixture combustion, penetration of fuel spray across the combustion chamber wall, and leakages in the fuel injector system (Annamalai et al., 2016). At low load engine operation, more HC 
formation was observed for all test fuels operated at different compression ratios of CR 16:1, CR 17:1 and CR 18:1. More accumulation of fuel molecules in the combustion chamber reduces engine combustive products reaction temperature is a credible reason for higher $\mathrm{HC}$ emission (Prasada Rao et al. 2017). An increase in $B P$ and $C R$ makes a significant reduction in $\mathrm{HC}$ formation. Likely, the rise in green diesel percentage on neat diesel fuel reduces the formation of unburned $\mathrm{HC}$ emissions. The reason is higher cetane number, availability of oxygen molecules in the green diesel enhances the air-fuel mixture rate and vaporization (Balasubramanian et al. 2018). At peak power outputs, $\mathrm{HC}$ formation is decreased by $39.13 \%$ for diesel, $43.07 \%$ for TCB30, $46.04 \%$ for TCB $50,42.59 \%$ for TCB70 and $37.5 \%$ for TCB100 when compared to low load condition operated at the CR 18:1. Higher CR 18:1 increases the cylinder pressure and temperature inside the combustion chamber, shorter the ID period, leading to better fuel combustion resulted in lower HC formation (Dhingra et al. 2014).

\section{Carbon monoxide emission (CO)}

The variation of $\mathrm{CO}$ emission with CR 16:1, CR 17:1 and CR 18:1 running at low load and full load conditions are plotted in Fig. 10. It shows that more $\mathrm{CO}$ formation in the neat diesel fuel operation equated with green diesel blends. The deficiency of $\mathrm{O}_{2}$ content in the neat diesel fuel forms higher $\mathrm{CO}$ operated at low and peak power outputs (Musthafa et al., 2018). However, the presence of oxygen content in the green diesel promotes complete oxidation of carbon monoxide (CO) into carbon-di-oxide $\left(\mathrm{CO}_{2}\right)$ reduces the formation of $\mathrm{CO}$ emission at different modes of $\mathrm{CR}$ operations (Dhinesh et al. 2016). At low-load conditions, all the test fuels (Diesel, TCB30, TCB50, TCB70 and TCB100) have resulted in higher CO emission operated at the compression ratios of 16:1, 17:1 and 18:1. The important reasons are lower operating temperature, and the A/F mixture in the combustion chamber exhibited higher $\mathrm{CO}$ formation (Hawi et al., 2019). Notably, the $\mathrm{CO}$ emissions are diminished by $43.06 \%$ for diesel fuel, $44.78 \%$ for TCB30, $48.39 \%$ for TCB50, $51.67 \%$ for TCB70 and $0.011 \%$ for TCB100 operated at CR $18: 1$ when correlated with top load state. But, the CO levels are higher for other compression ratios of 16:1 and 17:1. It is mainly due to the increase in CR increases the in-cylinder air temperature reduces the ignition delay period (ID) causes complete burning of the test fuels (Shameer and Ramesh 2017).

\section{Oxides of nitrogen emission $\left(\mathrm{NO}_{\mathrm{x}}\right)$}

The $\mathrm{NO}_{\mathrm{x}}$ formation in the $\mathrm{Cl}$ engines depends on the air-fuel mixture rate, in-cylinder combustion temperature, and $\mathrm{O}_{2}$ content in the intake air and test fuel (Manimaran et al., 2019). Figure 11 shows the variation of $\mathrm{NO}_{\mathrm{x}}$ emission with the influence of different input variables (BP, $\mathrm{CR}$ and TCB blend) under low load and high load operations. The graph observed that the increase in compression ratio increases the $\mathrm{NO}_{x}$ formation for all test fuels. The engine at high load operation produces higher in-cylinder temperature lead to $\mathrm{NO}_{x}$ formation. Similarly, an increase in the green diesel ratio on neat diesel increases the formation of $\mathrm{NO}_{\mathrm{x}}$. This is due to the proportional increment of $\mathrm{O}_{2}$ molecules, density of the green 
diesel leading to peak in-cylinder gas temperature, and most negligible radiative heat losses develops higher $\mathrm{NO}_{\mathrm{x}}$ (Rashed et al.2016). The test engine operated at the $\mathrm{CR}$ 18:1 generates a higher temperature inside the combustion chamber during the compression stroke results in more $\mathrm{NO}_{\mathrm{x}}$ (Koten 2018).

However, the engine operated at lower $\mathrm{CR} 16: 1$ produce lesser $\mathrm{NO}_{\mathrm{x}}$ emission due to a reduction in flame formation temperature, and localized in-cylinder gas temperature leads to $\mathrm{NO}_{\mathrm{x}}$ as small during low load engine operations (Sathiyamoorthi and Sankaranarayanan 2016). Among other TCB blends, the TCB30 shows lesser $\mathrm{NO}_{\mathrm{x}}$ emission, and it was reduced by $7.82 \%$ than TCB30, $10.89 \%$ than TCB50 and $14.62 \%$ than TCB100, respectively.

\section{Smoke opacity emission (\%)}

In general, the smoke opacity was formed due to the disproportion of the A/F ratio and unavailability of $\mathrm{O}_{2}$ in the fuel-rich pockets (Ramesh et al., 2019). Figure 12 illustrated the variation of smoke opacity for different compression ratios and fuel blends, namely TCB30, TCB50, TCB70 and TCB100 at low load and full load conditions. An increase in brake power gradually increases the test fuel admission into the engine cylinder to maintain the engine speed at the constant value of $1500 \mathrm{rpm}$, which leads to a higher smoke level (Anand et al., 2010). But, the increase in green diesel percentage on neat diesel resulted in minimal smoke opacity except for TCB100. The absence of aromatic compounds and lower carbon (C) to hydrogen $(\mathrm{H})$ ratio in the green diesel blends leads to better fuel atomization, and efficient combustion lowers smoke opacity formation (Ashok et al. 2018). The higher viscosity and the larger fuel droplet size of TCB100 promote higher smoke emission (Ganesan et al., 2020). At peak load condition, the CR 18:1 resulted in lower smoke levels, and it was diminished by $14.43 \%$ for TCB30, $24.87 \%$ for TCB $50,36.04 \%$ for TCB70 and $12.52 \%$ for TCB100 when compared to neat diesel. The high combustion pressure and temperature generated at the CR 18:1 operation improve combustion efficiency resulting in lesser smoke. But, the lower CR of 16:1 and 17:1 results in more smoke emission than CR 18:1. It may be credited to longer ID makes slow-burning, and lower in-cylinder gas temperature causes fuel combustion as incomplete is the reason for more smoke formation (Gnanamoorthi and Devaradjane 2015).

\section{Carbon dioxide emission $\left(\mathrm{CO}_{2}\right)$}

Figure 13 depicts the variation of $\mathrm{CO}_{2}$ emission against different $\mathrm{CR}$ and TCB blend operated at the minimum and maximum loading conditions. The graph observed that the varying CR from 16:1 to 18:1 gradually increases the $\mathrm{CO}_{2}$ emission levels for all test fuels. This is due to the complete combustion of test fuels ultimately converts the formation of $\mathrm{CO}$ into $\mathrm{CO}_{2}$ reduces $\mathrm{CO}_{2}$ emission (Ramalingam et al. 2020). Correspondingly, the percentage increase in green diesel on diesel fuel causes more $\mathrm{CO}_{2}$ emission due to increasing the percentage of $\mathrm{O}_{2}$ content in the TCB blend oxidize the shape of $\mathrm{CO}$ into $\mathrm{CO}_{2}$ produces a higher percentage of $\mathrm{CO}_{2}$ emission in the green diesel combustive products (Parida et al. 2019). At maximum power output, the value of $\mathrm{CO}_{2}$ emission is lower for diesel fuel (7.81\%), and the 
remaining test blends of TCB30 (9.21\%), TCB50 (9.52\%), TCB70 (10.27\%), and TCB100 (10.42\%) shows higher $\mathrm{CO}_{2}$ emissions powered at $\mathrm{CR} 18: 1$. But, the $\mathrm{CR} 16: 1$ and $17: 1$ shows lower $\mathrm{CO}_{2}$ formation. Notably, the $\mathrm{CO}_{2}$ emissions are increased by $17.93 \%, 21.89 \%, 31.25 \%$ and $33.41 \%$ for TCB30, TCB50, TCB70, and TCB100, respectively, when compared to neat diesel fuel. The main reason is the development of combustion temperature around $150{ }^{\circ} \mathrm{C}$; the more availability of $\mathrm{O}_{2}$ content in the green diesel improves the combustion rate, leading to more $\mathrm{CO}_{2}$ formation functioning at the higher $\mathrm{CR}$ 18:1 (Pradhan et al. 2017).

\section{Artificial Neural Networks (ANN)}

ANN has an intersect collection of neurons to develop the critical regression model to resolve the forecasting and decision-making problems (Venugopal et al., 2018). The prediction of engine process parameters using the ANN technique is unique compared to simulation software and mathematical models. However, selecting an appropriate network is vital for ANN model precision (Uslu and Celik 2020). ANN model consists of three layers: the input layer, hidden layer, and output layer. The input layer is linked with the output layer through the hidden layer. The bias and weights are updated in the hidden layer with the calculation of error between the experimental and predicted values until the error as small.

For all input parameters, a trained ANN model was simulated to achieve the corresponding outputs. The regression correlation coefficient $\left(\mathrm{R}^{2}\right)$, MAPE, and RMSE were calculated using the ANN model's targets and outputs in the following Eqs. (2) - (4)

Correlation coefficient $\left(\mathrm{R}^{2}\right)=1-\left(\frac{\sum_{i=1}^{n}\left(x_{i}-y_{i}\right)^{2}}{\sum_{i=1}^{n} y_{i}^{2}}\right)$

Mean Absolute Percentage Error (MAPE) $=\frac{100}{n} \sum_{i=1}^{n}\left|\frac{x_{i}-y_{i}}{y_{i}}\right| \%$

Root Mean Square Error $(\mathrm{RMSE})=\sqrt{\frac{1}{n} \sum_{i=1}^{n}\left(x_{i}-y_{i}\right)^{2}}$

Where, $\mathrm{x}$ - actual value, $\mathrm{y}$ - predicted value, $\mathrm{n}$ - number of marks in the data group

The proposed ANN model workflow chart is displayed in Fig. 14. In part 1, the input factors are biodiesel blend (B), engine load ( $L$ ) and compression ratio (CR) was introduced for network creation. Randomly 53 data $(70 \%)$ chosen from the experimental results were used for the training set, 11 data (15\%) selected for the validation set and the remaining 11 data (15\%) was used in the testing set. Secondly, it has been trained with this input information to obtain the best ANN model to evaluate the training, validation and test cycles. The last part is applied for ANN accuracy control and collection of data. 


\section{ANN modeling}

The neural network tool in MATLAB has been selected for this research work to predict diesel engine performance and emission characteristics. The ANN model is developed based on the FFBP (feedforward back propagation algorithm), the most commonly used algorithm. It is used for the training of experimental test data. Levenberg-Marquardt (TRAINLM) has applied to predict the MSE (mean square error) directed neural network loss function. The Hyperbolic tangent sigmoid (TANSIG) transfer function produces better results, making the ANN model more significant. Figure 15 shows that the selected topology for the prediction of engine output variables is 3-12-8. Initially, the 3 neurons of biodiesel blend (B), engine load (L) and compression ratio (CR) located in the input layer, and the output layer consist of 8 neurons are performance (BTE, BSFC and EGT) and emission ( $\mathrm{HC}, \mathrm{CO}, \mathrm{CO}_{2}, \mathrm{NO}_{\mathrm{x}}$ and smoke) parameters. The generation of unique code optimizes the hidden layer and is observed by the variation of RMSE with respect to the number of neurons, as shown in Fig. 16. It indicates the maximum error trained with a minimum number of neurons known as the underfitting zone. As the number of neurons is maximum, the training error decreases. But, the gap between training, validation and testing error increases, represented as the overfitting zone. From the above observations, the error and gap between all data sets are minimum at the optimal neuron of 12. It has been selected as the optimal neuron in the hidden layer of the neural network.

Based on input and output variables, the multiple regression model was generated using ANN. Figure 17 indicates the overall regression fit for training, validation and test sets. It shows that the correlation coefficient $(R)$ values of training, validation, test, and overall are $0.99798,0.99619,0.99092$ and 0.99673 , respectively. These obtained $\mathrm{R}^{2}$ values are about 1 , which indicates the high precision of the ANN model output responses.

\section{Sensitivity analysis of ANN model}

Sensitivity analysis evaluates the effect of specific input factors to grade their importance equivalent to the output responses. According to the importance of input factors, efficient and inefficient variables are evaluated. The inefficient variables are eliminated from the ANN model. It will simplify the numerical model and reducing training time (Ibrahim et al. 2019). The backward stepwise was found from the literature reviews as the simple method for ANN model sensitivity analysis. The engine load, biodiesel blend, and compression ratio were used to conduct the ANN model's sensitivity analysis. From Table 5, the ANN model 1 trained with all the input factors gives $\mathrm{R}^{2}$ and RMSE values of 0.99445 and 7.5126 . Removal of the compression ratio from the training data set moderately increases the RSME value. It shows that the effect of compression ratio is inefficient for the numerical model. Next, the biodiesel blend was omitted, and their $\mathrm{R}^{2}$ and RMSE data are 0.97712 and 21.0544, which implies the lesser contribution in the ANN model. Finally, model 4 resulted in the $\mathrm{R}^{2}$ of 0.44173 and RMSE of 140.7514 , presents the 
importance of engine load. The $\mathrm{R}^{2}$ value is drastically decreased, with error increases (RMSE). Therefore, it was concluded that the engine load is the most efficient variable on the ANN model.

Table 5

Sensitivity analysis of the ANN model

\begin{tabular}{|llllll|}
\hline ANN model & Engine load & Biodiesel blend & Compression ratio & $\mathbf{R}^{\mathbf{2}}$ & RMSE \\
\hline 1 & Yes & Yes & Yes & 0.99445 & 7.5126 \\
\hline 2 & Yes & Yes & No & 0.99378 & 8.7584 \\
\hline 3 & Yes & No & Yes & 0.97712 & 21.0544 \\
\hline 4 & No & Yes & Yes & 0.44173 & 140.7514 \\
\hline
\end{tabular}

\section{Performance of ANN model}

Figure 18. indicates the evaluation of experimental values with ANN predicted values for engine performance parameters. Notably, the $\mathrm{R}^{2}$ values of BTE, BSFC and EGT are 0.9988, 0.9996 and 0.9983, respectively. Similarly, the RSME values are minimum for all performance outputs. The correlation coefficient $\left(R^{2}\right)$ values are closer to 1 indicates the high accuracy of the proposed ANN model. It shows that using the proposed ANN model is ample to predict the engine performance parameters of BTE, BSFC and EGT.

The engine emission parameters are evaluated by interpretation of experimental and predicted values are shown in Fig. 19. The correlation coefficient $\left(R^{2}\right)$ values were found as $0.9968,0.9994,0.9996,0.9636$ and 0.9994 concerning emission variables of $\mathrm{HC}, \mathrm{CO}, \mathrm{NO}_{x}$, smoke opacity and $\mathrm{CO}_{2}$. The error and correlation output responses are obtained from the proposed ANN model is minimum. It indicates that the proposed ANN model is enough to forecast exhaust emissions.

\section{Conclusion}

In this study, the effect of brake power (L), TCB blend (B) and compression ratio (CR) on diesel engine performance and emission parameters are tested and predicted. The following conclusions are made based on the experimental and ANN model results obtained from the engine input factors and output responses.

- The green diesel $(T C B)$ with the yield of $92.7 \pm 0.4 \%$ was produced from the waste biomass of trichosanthes cucumerina seeds, and their fuel characterization was done.

- The different proportions of TCB blends (TCB30, TCB50, TCB 70 and TCB100) and neat diesel fuel are used in the VCR engine operations and obtain their performance and emission results. At full 
load conditions, all the TCB blends showed improved engine performance and reduced emission levels operated at the CR 18:1.

- The TCB30 blend shows an improved BTE of $33.52 \%$ correlated with other test fuels at full load conditions. But, it was decreased by $1.25 \%$ of BTE with the increment of BSFC by $2.27 \%$ than neat diesel fuel operated at the CR 18:1. Similarly, a higher EGT was obtained for all TCB blends.

- At higher CR 18:1, the TCB30 blend results that the HC, $\mathrm{CO}$ and smoke opacity were decreased by $13.51 \%, 10.82 \%$, and $16.87 \%$, respectively. But, the $\mathrm{NO}_{\mathrm{x}}$ and $\mathrm{CO}_{2}$ emissions are increased by $14.56 \%$ and $15.2 \%$ compared to neat diesel fuel operated at peak power outputs.

- The multiple regression ANN model was developed to forecast the engine performance (BTE, BSFC and $\mathrm{EGT})$ and emission $\left(\mathrm{HC}, \mathrm{CO}, \mathrm{NO}_{x}\right.$, smoke opacity and $\mathrm{CO}_{2}$ ) parameters. In the proposed ANN model, around 75 combinations of engine input and output variables are used for training, validation and test operations.

- The $\mathrm{R}^{2}$ values of training, validation, test and overall are obtained as $0.99798,0.99619,0.99092$ and 0.99673 . These $R^{2}$ values are about 1 , which provides exact output responses of the ANN model. It can reduce the experimental efforts and act as an effective tool for forecasting the engine process parameters under different operating conditions.

- Finally, the green diesel (TCB) and its blends are successfully operated in the selected VCR engine. It can be revealed that the TCB30 blend operated with CR 18:1 results in better engine performance and reduced exhaust emissions among all other TCB blends and compression ratios.

\section{Abbreviations}

ASTM American Society for Testing and Materials

ANN Artificial Neural Network

BTE Brake Thermal Efficiency

BSFC Brake Specific Fuel Consumption

CO Carbon monoxide

$\mathrm{CO}_{2}$ Carbon dioxide

DAS Data Acquisition System

EGT Exhaust Gas Temperature

FFA Free Fatty Acid

GC-MS Gas Chromatography-Mass Spectroscopy 
HC Hydrocarbon

$\mathrm{NO}_{\mathrm{x}}$ Oxides of Nitrogen

RSM Response Surface Methodology

TCO Trichosanthes Cucumerina bio-oil

TCB Trichosanthes Cucumerina biodiesel

TCB30 30\% Trichosanthes cucumerina biodiesel $+70 \%$ Diesel

TCB50 50\% Trichosanthes cucumerina biodiesel + 50\% Diesel

TCB70 70\% Trichosanthes cucumerina biodiesel $+30 \%$ Diesel

TCB100 100\% Trichosanthes cucumerina biodiesel

TGA Thermogravimetric analysis

VCR Variable Compression Ratio

\section{Declarations}

Ethics approval and consent to participate - Not applicable

Consent for publication - Not applicable

Availability of data and materials - Not applicable

Competing interests

The authors declare that they have no known competing financial interests or personal relationships that could have appeared to influence the work reported in this paper.

Funding - Not applicable

Authors' contributions

Rajayokkiam Manimaran: Conceptualization, Methodology, Writing - original draft, review \& editing. T. Mohan Raj: Supervision, Investigation. M. Venkatesan: Software, Resources.

Acknowledgements

The authors wish to convey their thanks to the School of Mechanical Engineering, SASTRA Deemed University, to provide laboratory facilities for carrying out the engine tests. 


\section{References}

1. Anand BP, Saravanan CG, Srinivasan CA (2010) Performance and exhaust emission of turpentine oil powered direct injection diesel engine. Renew Energy 35(6):1179-1184.

https://doi.org/10.1016/j.renene.2009.09.010

2. Annamalai M, Dhinesh B, Nanthagopal K, SivaramaKrishnan P, Isaac JoshuaRamesh Lalvani J, Parthasarathy M, Annamalai K (2016) An assessment on performance, combustion and emission behavior of a diesel engine powered by ceria nanoparticle blended emulsified biofuel. Energy Convers Manag 123:372-380. https://doi.org/10.1016/j.enconman.2016.06.062

3. Ashok B, Nanthagopal K, Sakthi Vignesh D (2018) Calophyllum inophyllum methyl ester biodiesel blend as an alternate fuel for diesel engine applications. Alex Eng J 57(3):1239-1247. https://doi.org/10.1016/j.aej.2017.03.042

4. Ashok B, Nanthagopal K, Saravanan B, Azad K, Patel D, Sudarshan B, Aaditya Ramasamy R (2019) Study on isobutanol and Calophyllum inophyllum biodiesel as a partial replacement in $\mathrm{Cl}$ engine applications. Fuel 235:984-994. https://doi.org/10.1016/j.fuel.2018.08.087

5. Aydın M, Uslu S, Bahattin Çelik M (2020) Performance and emission prediction of a compression ignition engine fueled with biodiesel-diesel blends: A combined application of ANN and RSM based optimization. Fuel 269:117472. https://doi.org/10.1016/j.fuel.2020.117472

6. Babu D, Thangarasu V, Ramanathan A (2020) Artificial neural network approach on forecasting diesel engine characteristics fuelled with waste frying oil biodiesel. Appl Energy 263. https://doi.org/10.1016/j.apenergy.2020.114612

7. Balasubramanian D, Sokkalingam Arumugam SR, Subramani L, Joshua Stephen Chellakumar IJRL, Mani A (2018) A numerical study on the effect of various combustion bowl parameters on the performance, combustion, and emission behavior on a single cylinder diesel engine. Environ Sci Pollut Res 25(3):2273-2284. https://doi.org/10.1007/s11356-017-0565-2

8. Baranitharan P, Ramesh K, Sakthivel R (2019) Measurement of performance and emission distinctiveness of Aegle marmelos seed cake pyrolysis oil/diesel/TBHQ opus powered in a DI diesel engine using ANN and RSM. Measurement 144:366-380.

https://doi.org/10.1016/j.measurement.2019.05.037

9. Dey S, Reang NM, Majumder A, Deb M, Das PK (2020) A hybrid ANN-Fuzzy approach for optimization of engine operating parameters of a $\mathrm{Cl}$ engine fueled with diesel-palm biodiesel-ethanol blend. Energy 202:117813. https://doi.org/10.1016/j.energy.2020.117813

10. Dharma S, Hassan MH, Ong HC, Sebayang AH, Silitonga AS, Kusumo F, Milano J (2017) Experimental study and prediction of the performance and exhaust emissions of mixed Jatropha curcas-Ceiba pentandra biodiesel blends in diesel engine using artificial neural networks. J Clean Prod 164:618-633. https://doi.org/10.1016/j.jclepro.2017.06.065

11. Dhinesh B, Isaac JoshuaRamesh Lalvani J, Parthasarathy M, Annamalai K (2016) An assessment on performance, emission and combustion characteristics of single cylinder diesel engine powered by 
Cymbopogon flexuosus biofuel. Energy Convers Manag 117:466-474.

https://doi.org/10.1016/j.enconman.2016.03.049

12. Dhingra S, Bhushan G, Dubey KK (2014) Multi-objective optimization of combustion, performance and emission parameters in a jatropha biodiesel engine using Non-dominated sorting genetic algorithm-II. Front Mech Eng 9(1):81-94. https://doi.org/10.1007/s11465-014-0287-9

13. Elsanusi OA, Roy MM, Sidhu MS (2017) Experimental investigation on a diesel engine fuelled by diesel-biodiesel blends and their emulsions at various engine operating conditions. Appl Energy 203:582-593. https://doi.org/10.1016/j.apenergy.2017.06.052

14. Ganesan S, Padmanabhan S, Mahalingam S, Shanjeevi C (2020) Environmental Effects

Environmental impact of VCR diesel engine characteristics using blends of cottonseed oil with nano additives. Energy Sources Part A Recover Util Environ Eff 42(6):761-772.

DOI:10.1080/15567036.2019.1602196

15. Ghobadian B, Rahimi H, Nikbakht AM, Najafi G, Yusaf TF (2009) Diesel engine performance and exhaust emission analysis using waste cooking biodiesel fuel with an artificial neural network. Renew Energy 34(4):976-982. https://doi.org/10.1016/j.renene.2008.08.008

16. Gnanamoorthi V, Devaradjane G (2015) Effect of compression ratio on the performance, combustion and emission of di diesel engine fueled with ethanol-Diesel blend. J Energy Inst 88(1):19-26. https://doi.org/10.1016/j.joei.2014.06.001

17. Hawi M, Elwardany A, Ookawara S, Ahmed M (2019) Effect of compression ratio on performance, combustion and emissions characteristics of compression ignition engine fueled with jojoba methyl ester. Renew Energy 141:632-645. https://doi.org/10.1016/j.renene.2019.04.041

18. Hosamani BR, Katti VV (2018) Experimental analysis of combustion characteristics of CI DI VCR engine using mixture of two biodiesel blend with diesel. Eng Sci Technol an Int J 21:769-777. https://doi.org/10.1016/j.jestch.2018.05.015

19. Hosseini SH, Taghizadeh-Alisaraei A, Ghobadian B, Abbaszadeh-Mayvan A (2020) Artificial neural network modeling of performance, emission, and vibration of a $\mathrm{Cl}$ engine using alumina nanocatalyst added to diesel-biodiesel blends. Renew Energy 149:951-961. https://doi.org/10.1016/j.renene.2019.10.080

20. Ibrahim S, Choong CE, El-Shafie A (2019) Sensitivity analysis of artificial neural networks for justsuspension speed prediction in solid-liquid mixing systems: Performance comparison of MLPNN and RBFNN. Adv Eng Inform 39:278-291. https://doi.org/10.1016/j.aei.2019.02.004

21. Işcan B (2020) ANN modeling for justification of thermodynamic analysis of experimental applications on combustion parameters of a diesel engine using diesel and safflower biodiesel fuels. Fuel 279. https://doi.org/10.1016/j.fuel.2020.118391

22. Karthic SV, Masimalai SK (2020) Predicting the performance and emission characteristics of a Mahua oil-hydrogen dual fuel engine using artificial neural networks. Energy Sources Part A Recovery Util Environ Eff 42(23):2891-2910. https://doi.org/10.1080/15567036.2019.1618997 
23. Karthickeyan V, Balamurugan P, Rohith G, Senthil R (2017) Developing of ANN model for prediction of performance and emission characteristics of VCR engine with orange oil biodiesel blends. J Braz Soc Mech Sci Eng 39(7):2877-2888. https://doi.org/10.1007/s40430-017-0768-y

24. Koten $\mathrm{H}$ (2018) Hydrogen effects on the diesel engine performance and emissions. Int J Hydrogen Energy 43(22):105-119. https://doi.org/10.1016/j.ijhydene.2018.04.146

25. Krishnamoorthi M, Malayalamurthi R, Sakthivel R (2019) Optimization of compression ignition engine fueled with diesel - chaulmoogra oil - diethyl ether blend with engine parameters and exhaust gas recirculation. Renew Energy 134:579-602. https://doi.org/10.1016/j.renene.2018.11.062

26. Lahane S, Subramanian KA (2014) Impact of nozzle holes configuration on fuel spray, wall impingement and NOx emission of a diesel engine for biodiesel-diesel blend (B20). Appl Therm Eng 64(1-2):307-314. https://doi.org/10.1016/j.applthermaleng.2013.12.048

27. Manimaran R, Murugu Mohan Kumar K, Hari Shankar V (2019) Study on novel nano mahua methyl ester powered DI diesel engine preheated with a thermoelectric waste heat recovery system. Energy Sources, Part A Recovery Util Environ Eff. DOI: 10.1080/15567036.2019.1587100

28. Mehra RK, Duan H, Luo S, Rao A, Ma F (2018) Experimental and artificial neural network (ANN) study of hydrogen enriched compressed natural gas (HCNG) engine under various ignition timings and excess air ratios. Appl Energy 228:736-754. https://doi.org/10.1016/j.apenergy.2018.06.085

29. Mohan B, Yang W, Raman V, Vedharai S, Chou SK (2014) Optimization of biodiesel fuelled engine to meet emission standards through varying nozzle opening pressure and static injection timing. Appl Energy 130:450-457. https://doi.org/10.1016/j.apenergy.2014.02.033

30. Musthafa MM, Kumar TA, Mohanraj T, Chandramouli R (2018) A comparative study on performance, combustion and emission characteristics of diesel engine fuelled by biodiesel blends with and without an additive. Fuel 225:343-348. https://doi.org/10.1016/j.fuel.2018.03.147

31. Nanthagopal K, Ashok B, Saravanan B, Ramesh Pathy M, Sahil G, Ramesh A, Nurun Nabi M, Golam Rasul M (2019) Study on decanol and Calophyllum Inophyllum biodiesel as ternary blends in $\mathrm{Cl}$ engine. Fuel 239:862-873. https://doi.org/10.1016/j.fuel.2018.11.037

32. Parida MK, Joardar H, Rout AK, Routaray I, Mishra BP (2019) Multiple response optimizations to improve performance and reduce emissions of Argemone Mexicana biodiesel-diesel blends in a VCR engine. Appl Therm Eng 148:1454-1466. https://doi.org/10.1016/j.applthermaleng.2018.11.061

33. Pradhan D, Bendu H, Singh RK, Murugan S (2017) Mahua seed pyrolysis oil blends as an alternative fuel for light-duty diesel engines. Energy 118:600-612. https://doi.org/10.1016/j.energy.2016.10.091

34. Prasada Rao K, Victor Babu T, Anuradha G, Appa Rao BV BV (2017) IDI diesel engine performance and exhaust emission analysis using biodiesel with an artificial neural network (ANN). Egypt J Pet 26(3):593-600. https://doi.org/10.1016/j.ejpe.2016.08.006

35. Ramalingam K, Balasubramanian D, Chellakumar PJTJS, Padmanaban J, Murugesan P, Xuan T (2020) An assessment on production and engine characterization of a novel environment-friendly fuel. Fuel 279:118558. https://doi.org/10.1016/j.fuel.2020.118558 
36. Ramalingam K, Kandasamy A, Balasubramanian D, Palani M, Subramanian T, Varuvel EG, Viswanathan K (2020) Forcasting of an ANN model for predicting behaviour of diesel engine energised by a combination of two low viscous biofuels. Environ Sci Pollut Res 27(20):2470224722. https://doi.org/10.1007/s11356-019-06222-7

37. Ramesh A, Ashok B, Nanthagopal K, Ramesh Pathy M, Tambare A, Mali P, Phuke P, Patil S, Subbarao $\mathrm{R}$ (2019) Influence of hexanol as additive with Calophyllum Inophyllum biodiesel for $\mathrm{Cl}$ engine applications. Fuel 249:472-485. https://doi.org/10.1016/j.fuel.2019.03.072

38. Rashed MM, Kalam MA, Masjuki HH, Habibullah M, Imdadul HK, Shahin MM, Rahman MM (2016) Improving oxidation stability and $\mathrm{NO}_{\mathrm{x}}$ reduction of biodiesel blends using aromatic and synthetic antioxidant in a light duty diesel engine. Ind Crops Prod 89(X):273-284. https://doi.org/10.1016/j.indcrop.2016.05.008

39. Sathiyamoorthi R, Sankaranarayanan G (2016) Effect of antioxidant additives on the performance and emission characteristics of a DICl engine using neat lemongrass oil-diesel blend. Fuel 174:8996. https://doi.org/10.1016/j.fuel.2016.01.076

40. Senthil Kumar M, Arul K, Sasikumar N (2019) Impact of oxygen enrichment on the engine's performance, emission and combustion behavior of a biofuel based reactivity controlled compression ignition engine. J Energy Inst 92(1):51-61. https://doi.org/10.1016/j.joei.2017.12.001

41. Sevinc $H$, Hazar $H$ (2020) Investigation of exhaust emissions of an isolated diesel engine blended with ethylhexyl nitrate using experimental and ANN approach. Environ Sci Pollut Res 27(27):3375333772. https://doi.org/10.1007/s11356-020-09373-0

42. Shameer PM, Ramesh K (2017) Influence of antioxidants on fuel stability of Calophyllum inophyllum biodiesel and RSM-based optimization of engine characteristics at varying injection timing and compression ratio. J Braz Soc Mech Sci Eng 39(11):4251-4273. https://doi.org/10.1007/s40430017-0884-8

43. Shivakumar S, Pai P, Shrinivasa Rao BR (2011) Artificial Neural Network based prediction of performance and emission characteristics of a variable compression ratio $\mathrm{Cl}$ engine using $\mathrm{WCO}$ as a biodiesel at different injection timings. Appl Energy 88(7):2344-2354. https://doi.org/10.1016/j.apenergy.2010.12.030

44. Subramani S, Govindasamy R, Rao GLN (2020) Predictive correlations for $\mathrm{NO}_{x}$ and smoke emission of DI Cl engine fuelled with diesel-biodiesel-higher alcohol blends-response surface methodology approach. Fuel 269:117304. https://doi.org/10.1016/j.fuel.2020.117304

45. Thiruvenkatachari S, Saravanan CG, Geo VE, Vikneswaran M, Udayakumar R, Fethi A (2021) Experimental investigations on the production and testing of azolla methyl esters from Azolla microphylla in a compression ignition engine. Fuel 287:119448. https://doi.org/10.1016/j.fuel.2020.119448

46. Uslu S, Celik MB (2018) Prediction of engine emissions and performance with artificial neural networks in a single cylinder diesel engine using diethyl ether. Eng Sci Technol Int J 21(6):11941201. https://doi.org/10.1016/j.jestch.2018.08.017 
47. Uslu S, Celik MB (2020) Performance and Exhaust Emission Prediction of a SI Engine Fueled with Iamyl Alcohol-Gasoline Blends: An ANN Coupled RSM Based Optimization. Fuel 265:116922. https://doi.org/10.1016/j.fuel.2019.116922

48. Vellaiyan S (2020) Enhancement in combustion, performance, and emission characteristics of a biodiesel-fueled diesel engine by using water emulsion and nanoadditive. Renew Energy 145:21082120. https://doi.org/10.1016/j.renene.2019.07.140

49. Venugopal P, Kasimani R, Chinnasamy S (2018) Prediction and optimization of $\mathrm{Cl}$ engine performance fuelled with Calophyllum inophyllum diesel blend using response surface methodology (RSM). Environ Sci Pollut Res 25(25):24829-24844. https://doi.org/10.1007/s11356-018-2519-8

50. Vigneswaran R, Annamalai K, Dhinesh B, Krishnamoorthy R (2018) Experimental investigation of unmodified diesel engine performance, combustion and emission with multipurpose additive along with water-in-diesel emulsion fuel. Energy Convers Manag 172:370-380.

https://doi.org/10.1016/j.enconman.2018.07.039

51. Wamankar AK, Satapathy AK, Murugan S (2015) Experimental investigation of the effect of compression ratio, injection timing \& pressure in a $\mathrm{DI}$ (direct injection) diesel engine running on carbon black-water-diesel emulsion. Energy 93:511-520. https://doi.org/10.1016/j.energy.2015.09.068

52. Yang F, Cho H, Zhang H, Zhang J, Wu Y (2018) Artificial neural network (ANN) based prediction and optimization of an organic Rankine cycle (ORC) for diesel engine waste heat recovery. Energy Convers Manag 164:15-26. https://doi.org/10.1016/j.enconman.2018.02.062

\section{Figures}
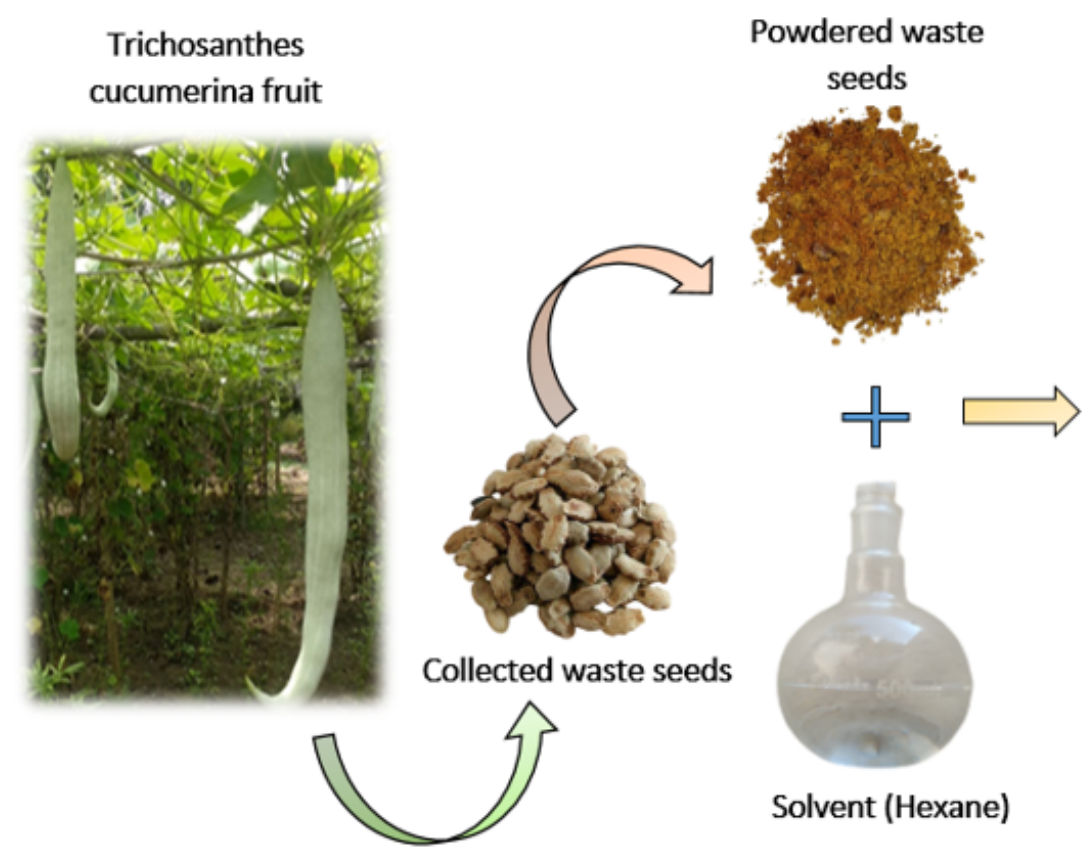

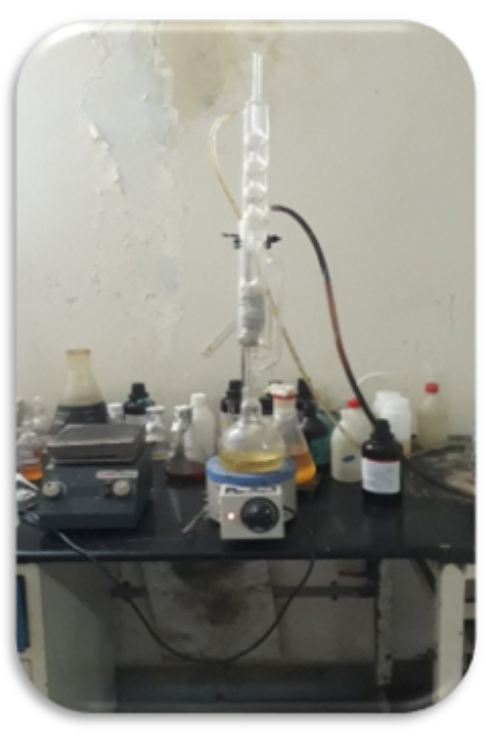

Soxhlet apparatus

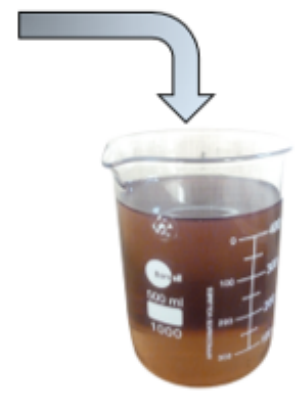

TCO

\section{Figure 1}




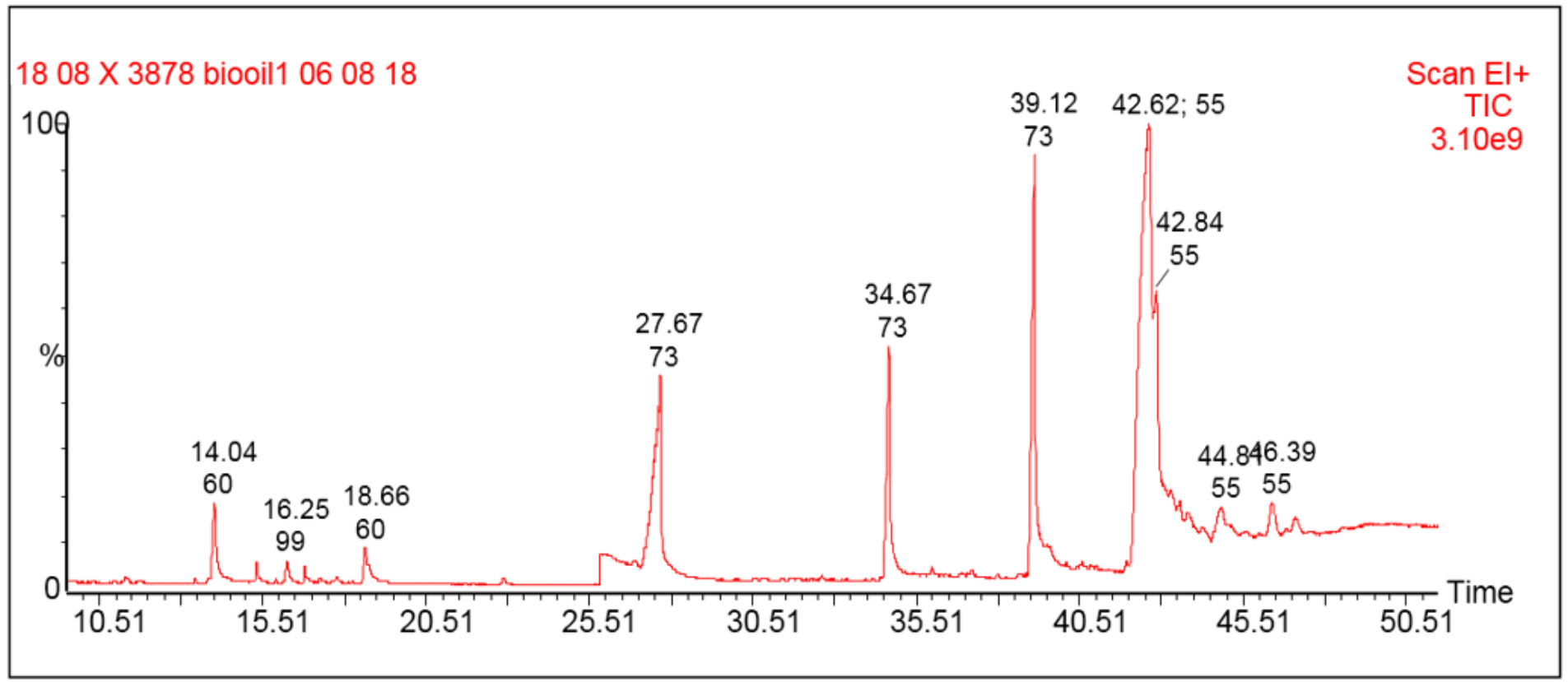

\section{Figure 2}

GC-MS analysis for TCO

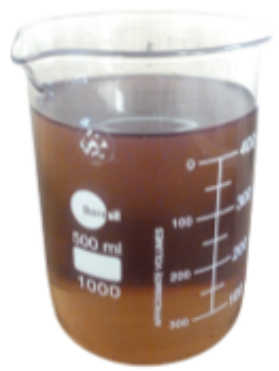

Neat TCO

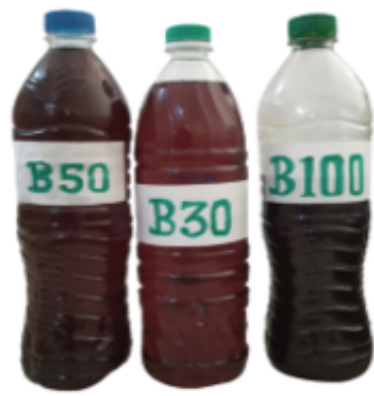

TCB blends

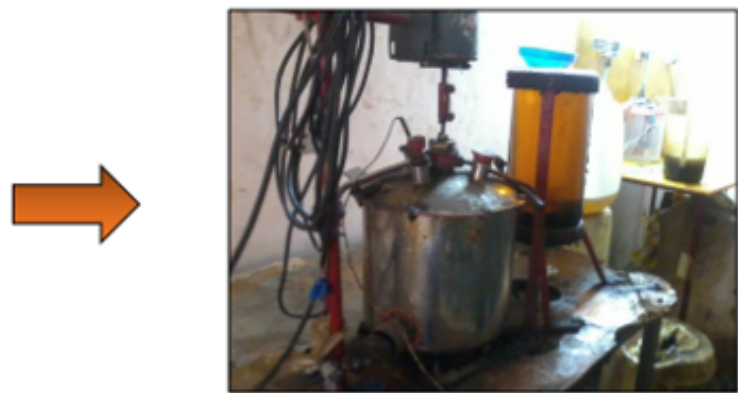

Trans-esterification of TCO
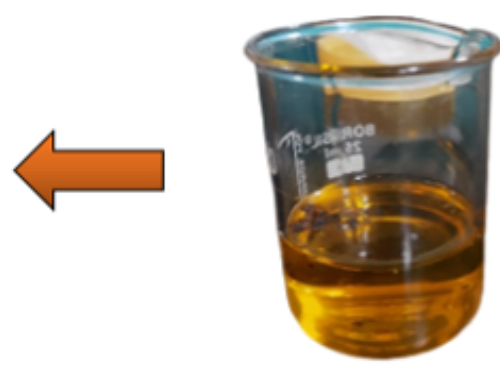

Green diesel

(TCB)

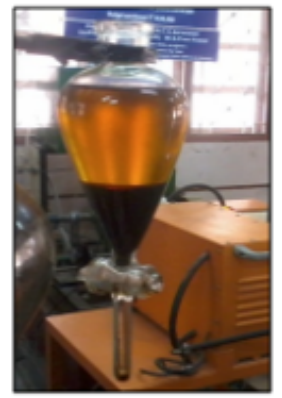

Visibility of two distinct layers

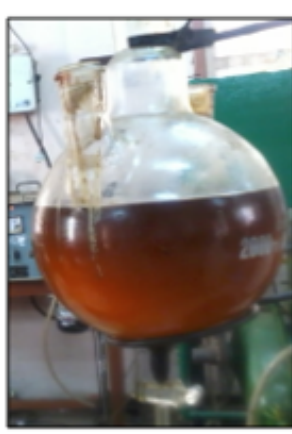

Purification of TCO

\section{Figure 3}

Trichosanthes cucumerina biodiesel (TCB) production process 


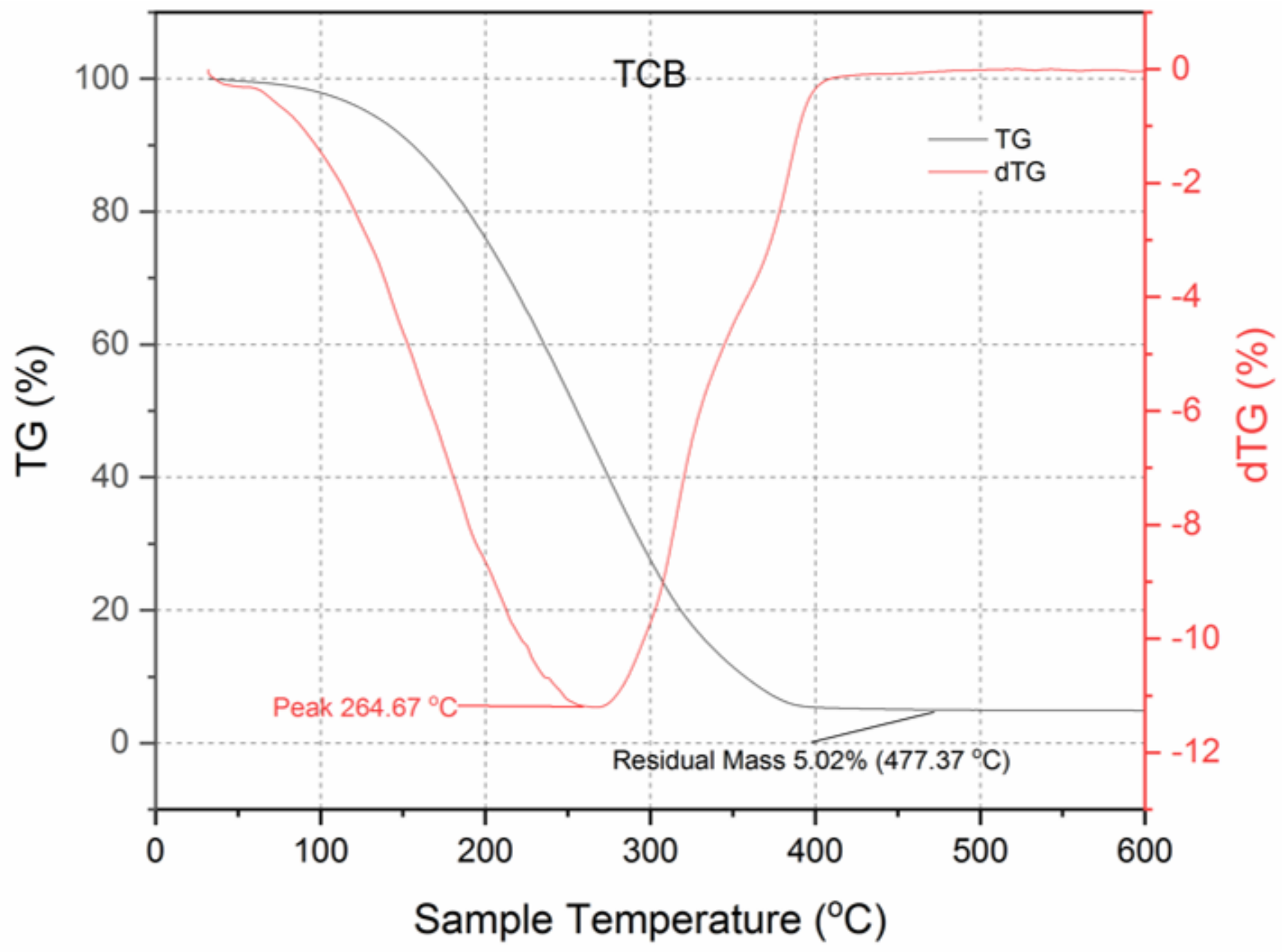

Figure 4

TGA analysis for TCB 


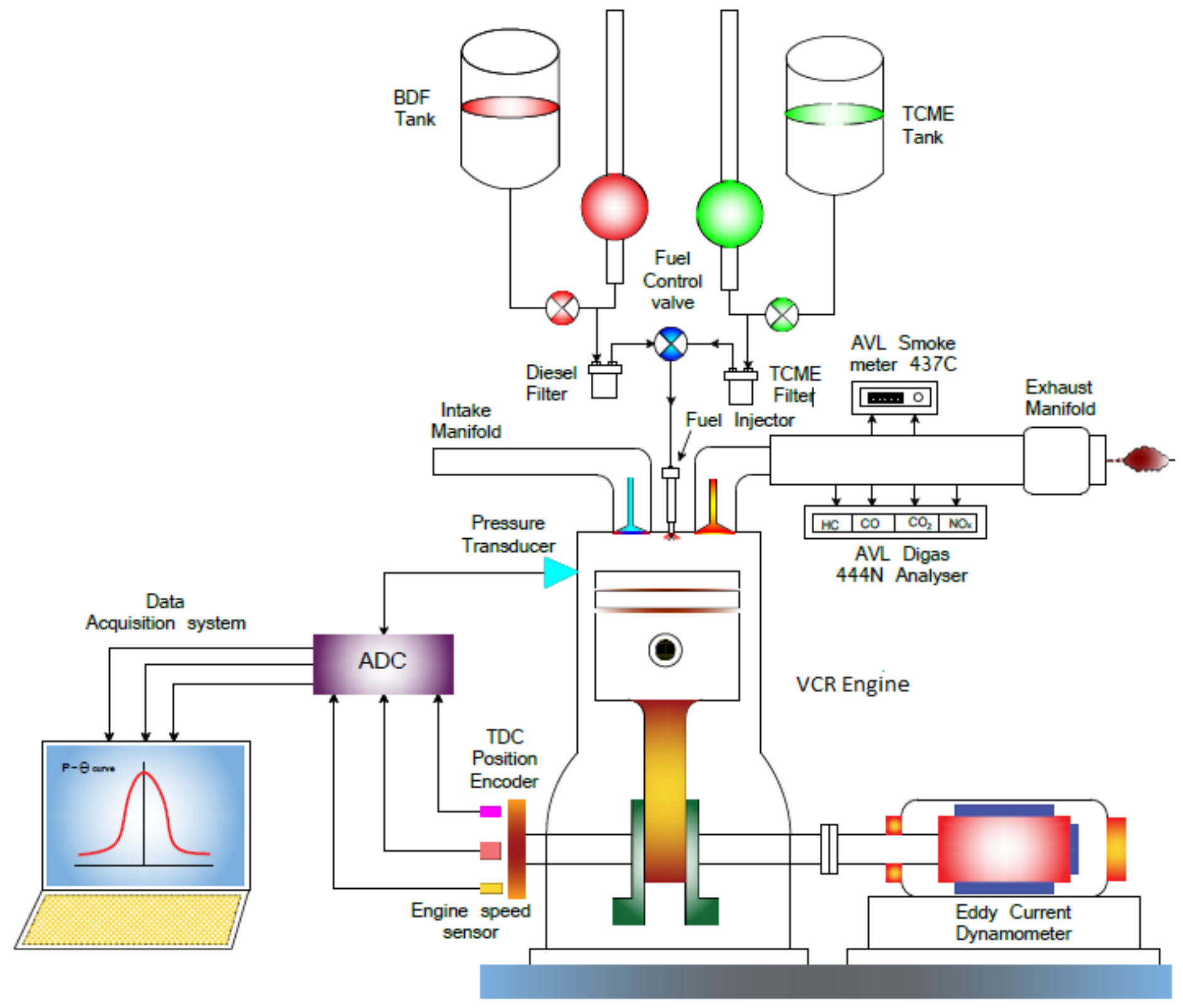

Figure 5

Engine experimental setup 

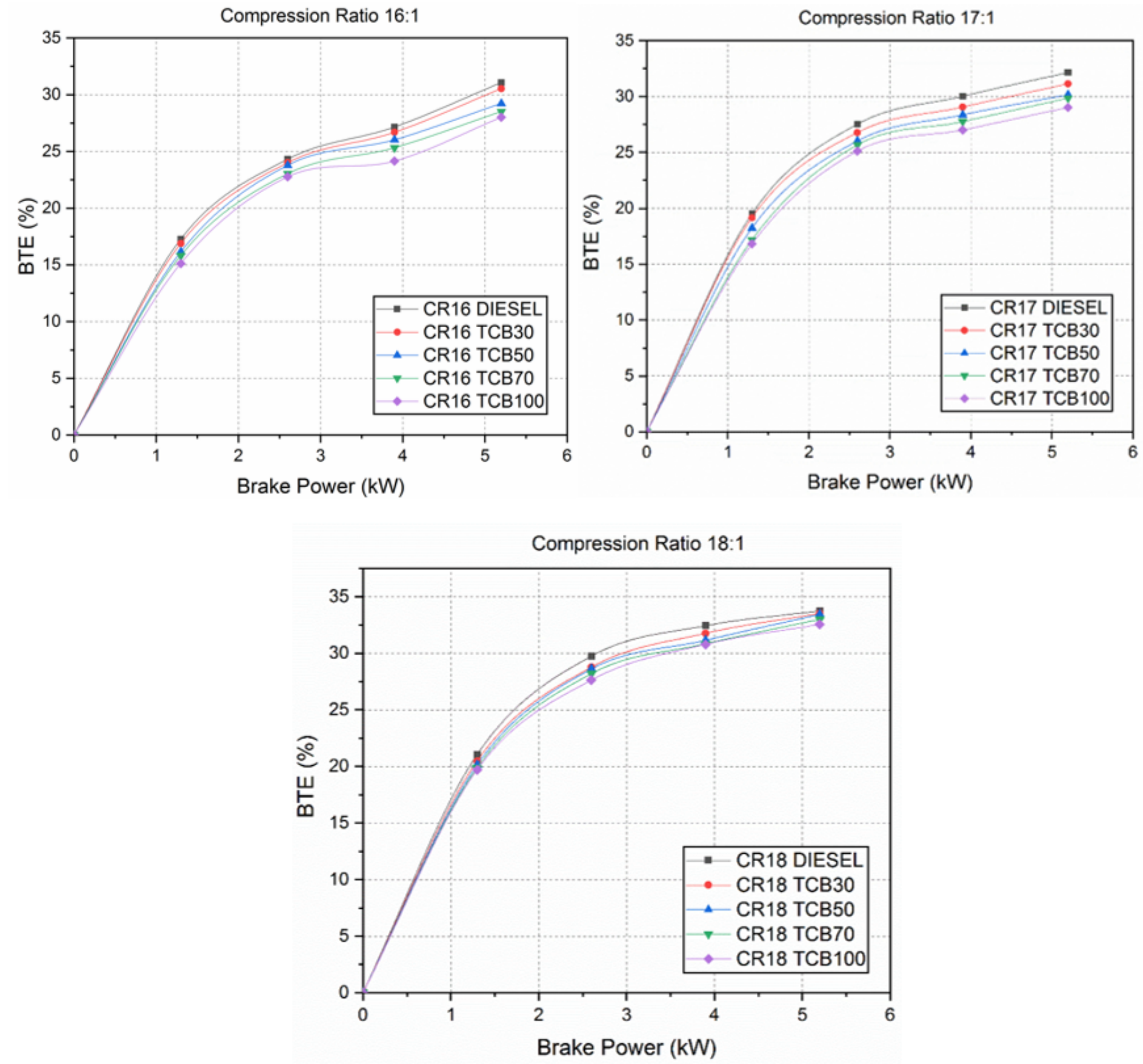

Figure 6

Variation of BTE with brake power for CR 16:1, CR 17:1 and CR 18:1 

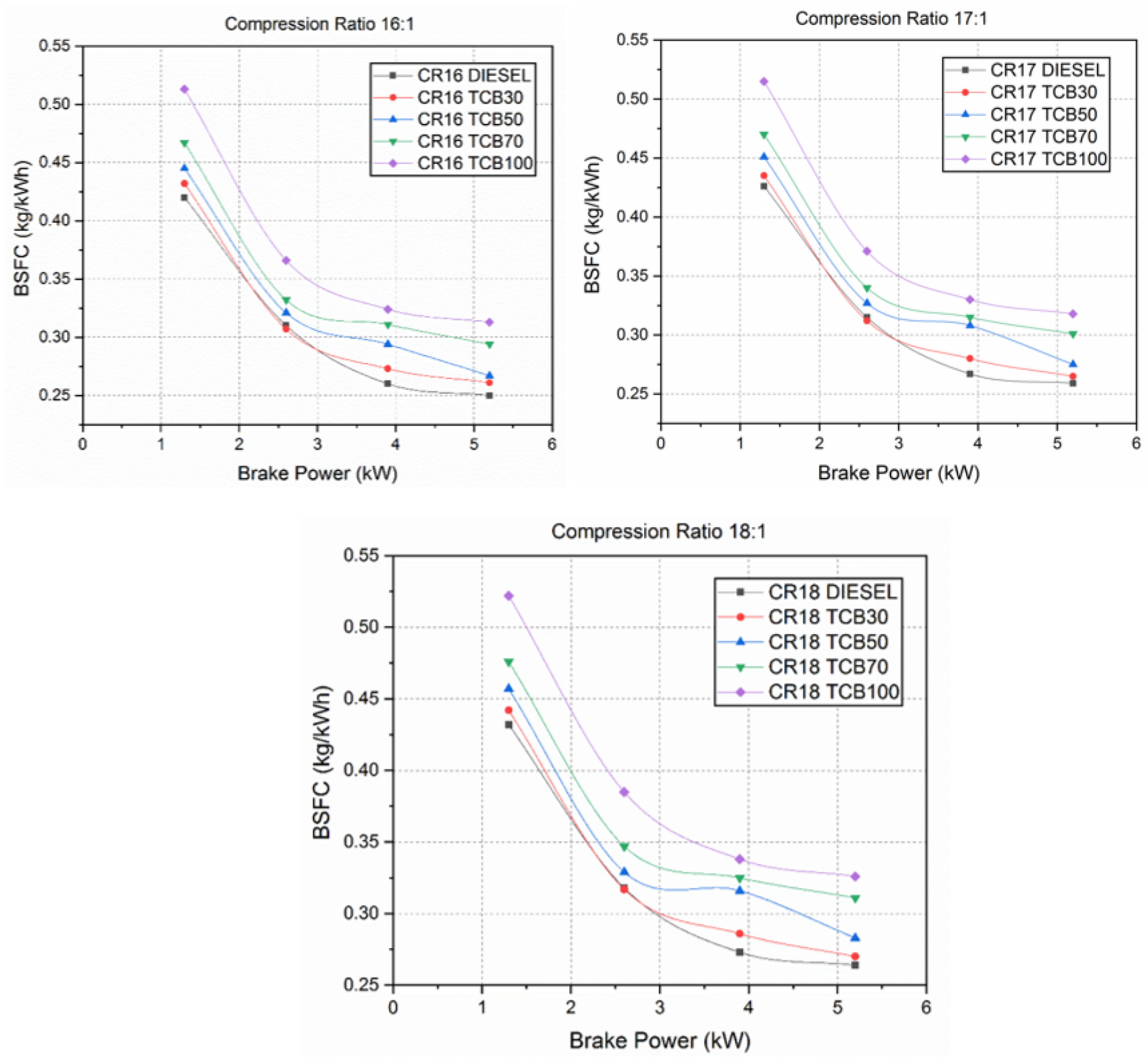

Figure 7

Variation of BSFC with brake power for CR 16:1, CR 17:1 and CR 18:1 

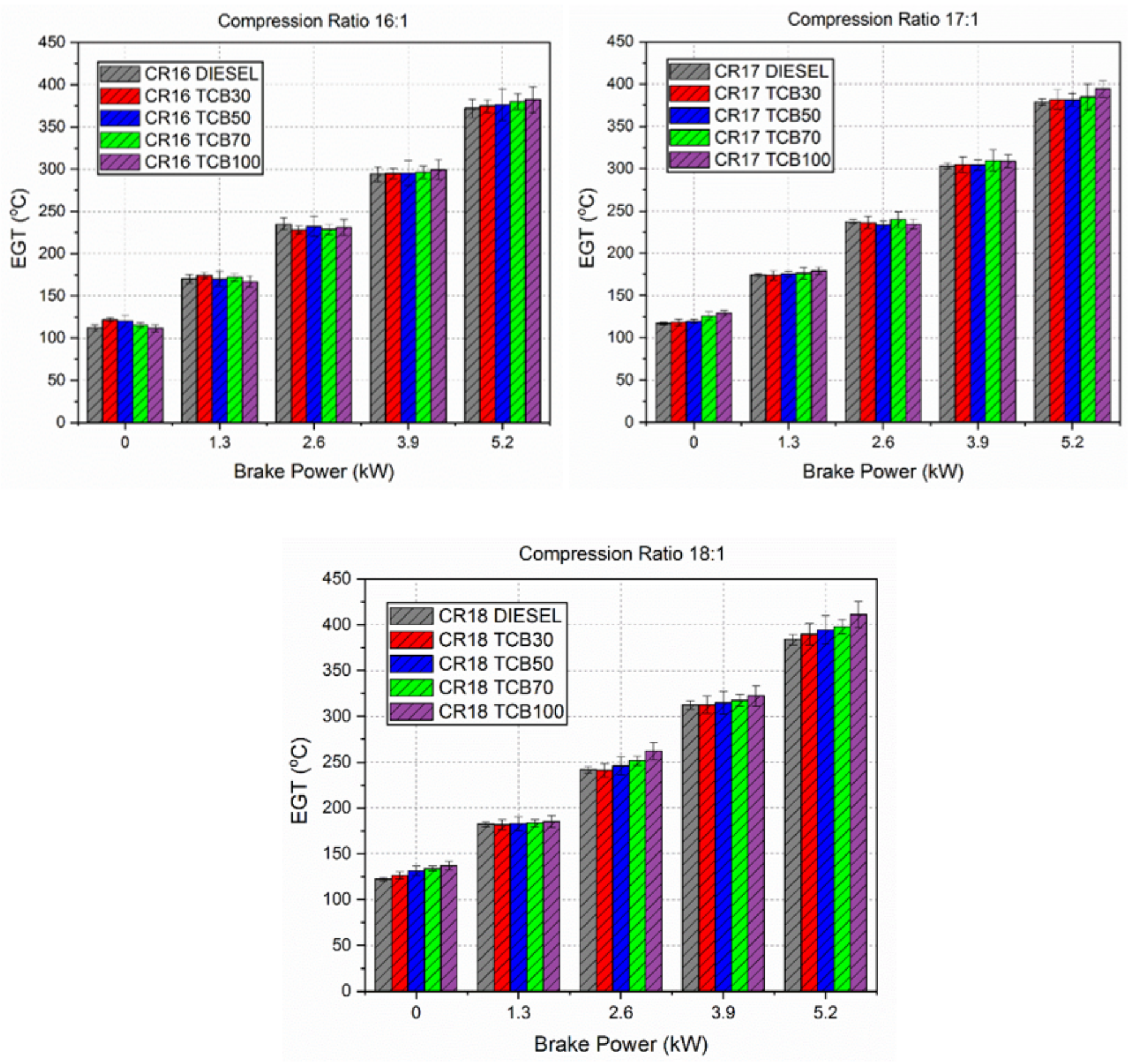

Figure 8

Variation of EGT with brake power for CR 16:1, CR 17:1 and CR 18:1 

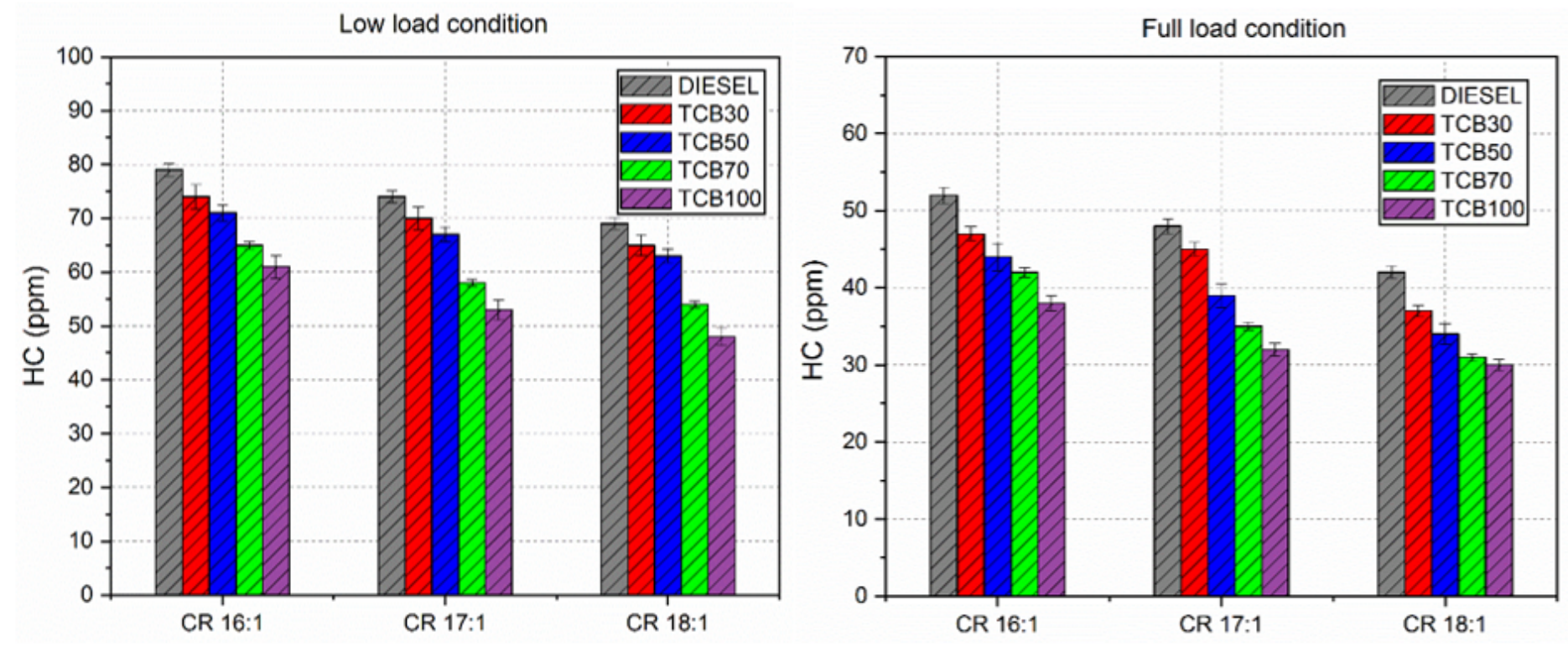

Figure 9

Variation of HC emission with CR 16:1, CR 17:1 and CR 18:1 operated at low load and full load condition
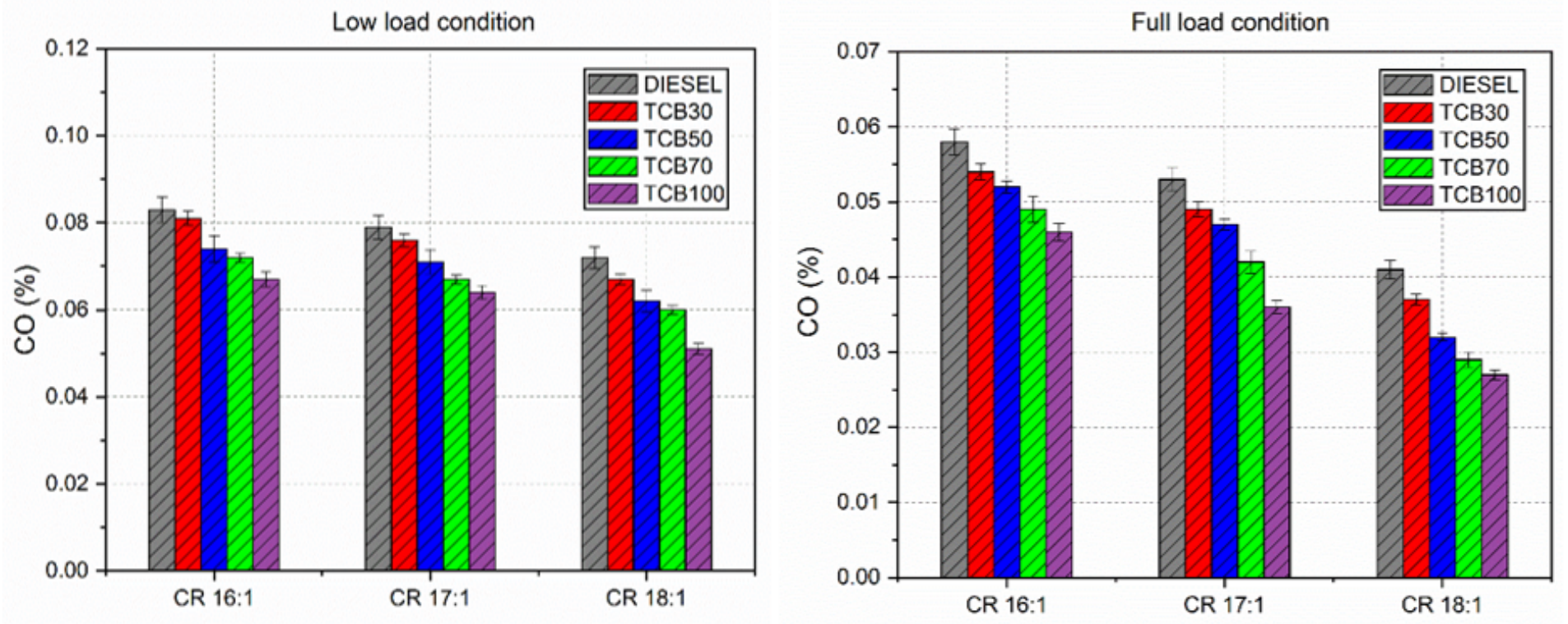

Figure 10

Variation of CO emission with CR 16:1, CR 17:1 and CR 18:1 operated at low load and full load condition 

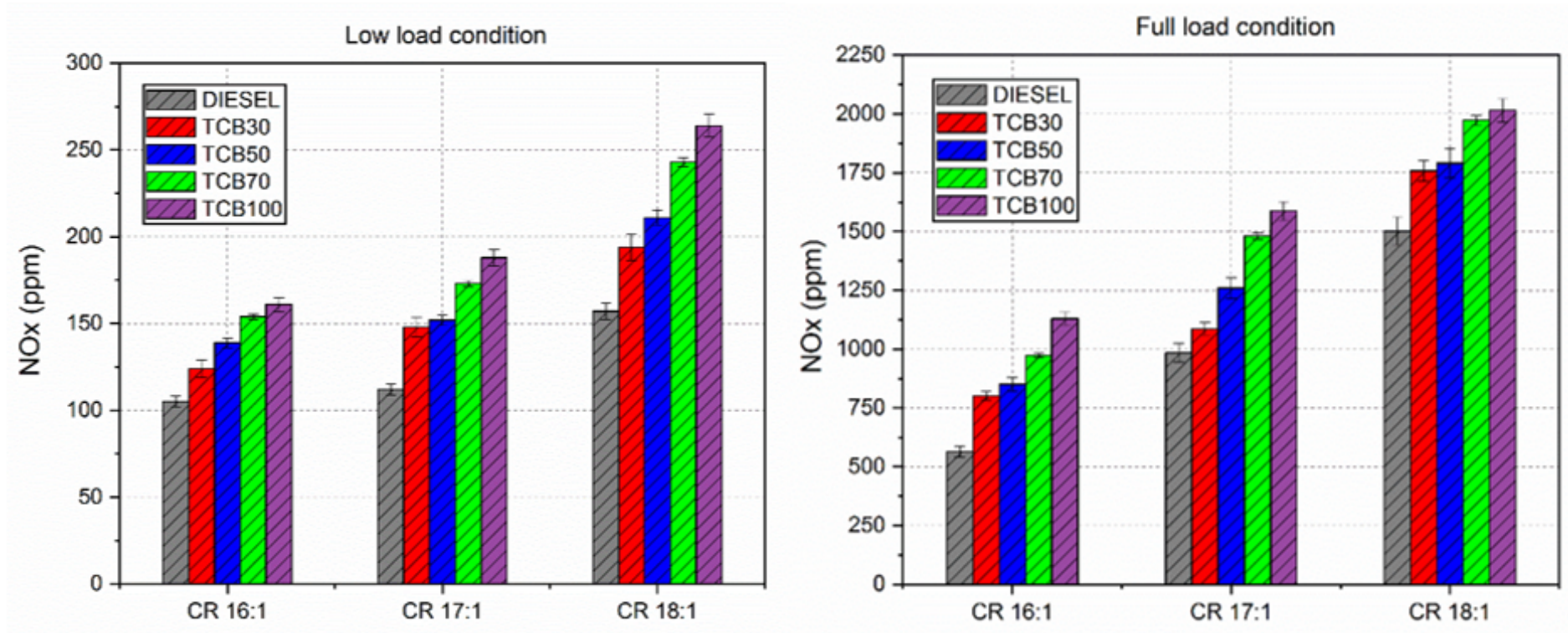

Figure 11

Variation of NOx emission with CR 16:1, CR 17:1 and CR 18:1 operated at low load and full load condition
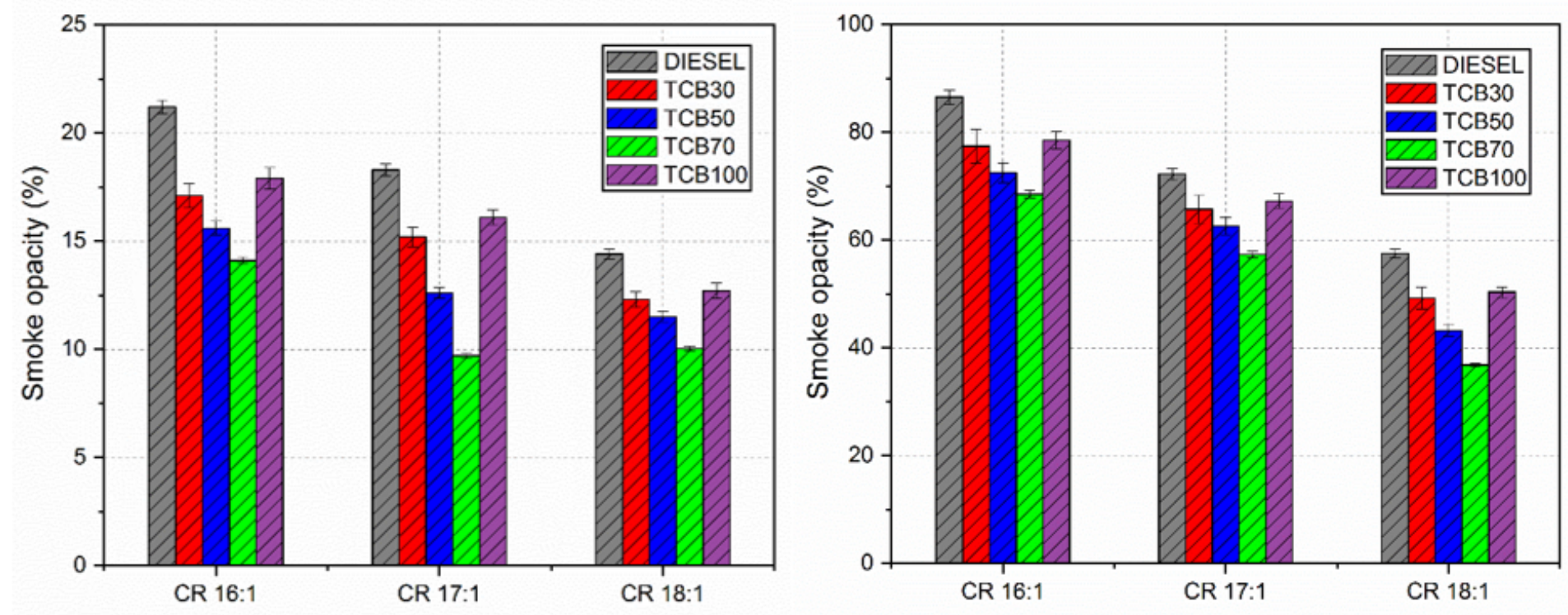

Figure 12

Variation of smoke opacity with CR $16: 1$, CR $17: 1$ and CR $18: 1$ operated at low load and full load condition 

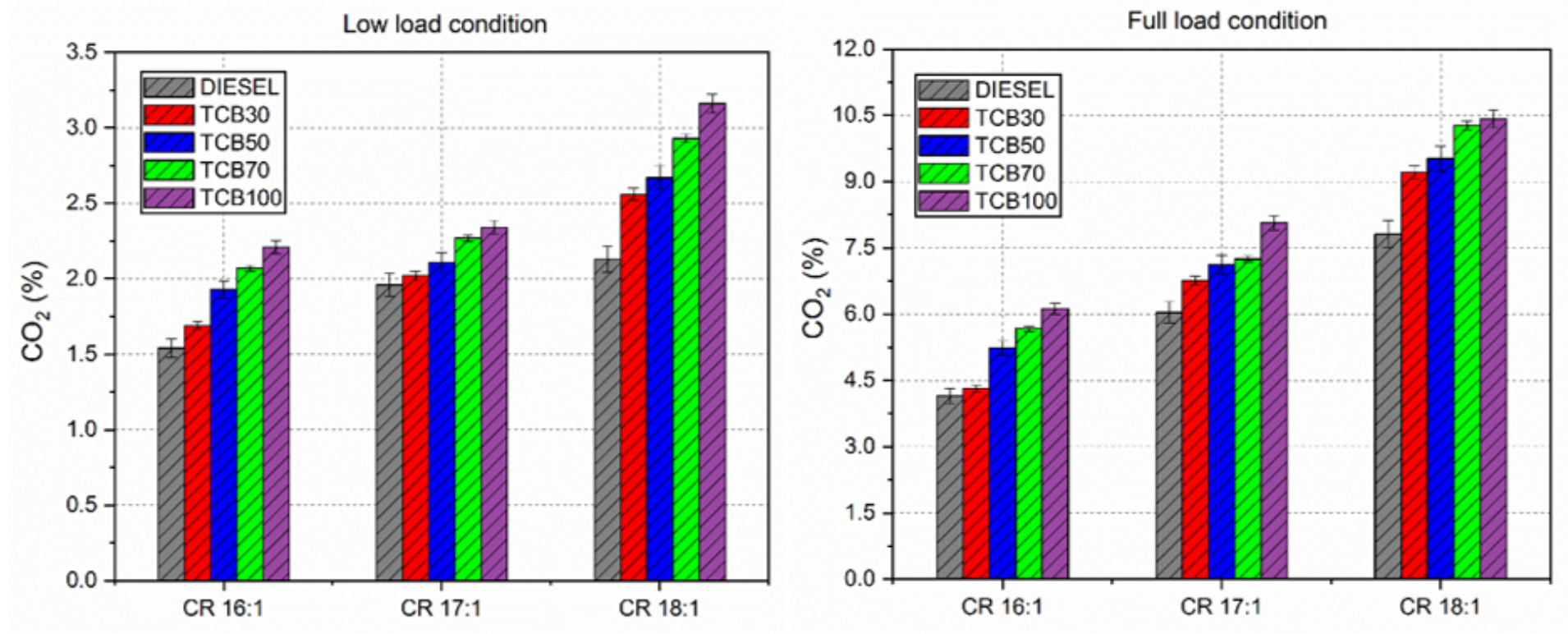

Figure 13

Variation of CO2 emission with CR 16:1, CR 17:1 and CR 18:1 operated at low load and full load condition 


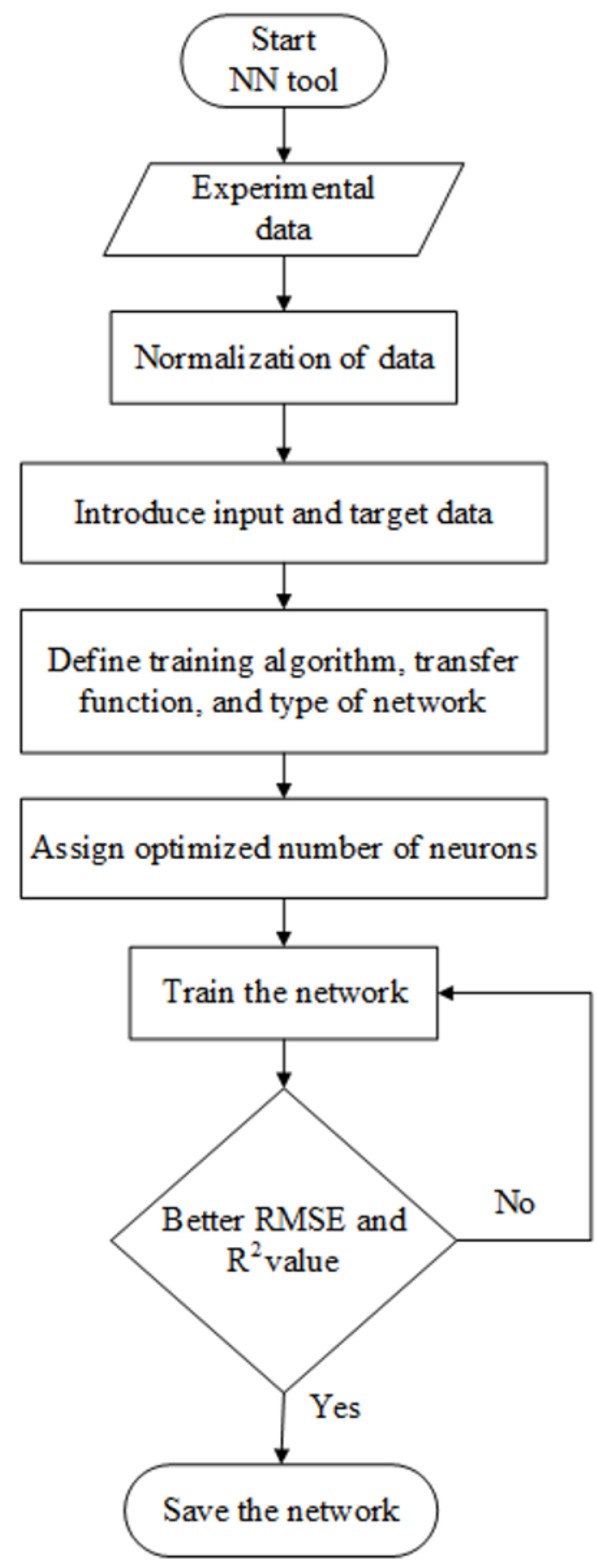

Figure 14

ANN model work flow chart 


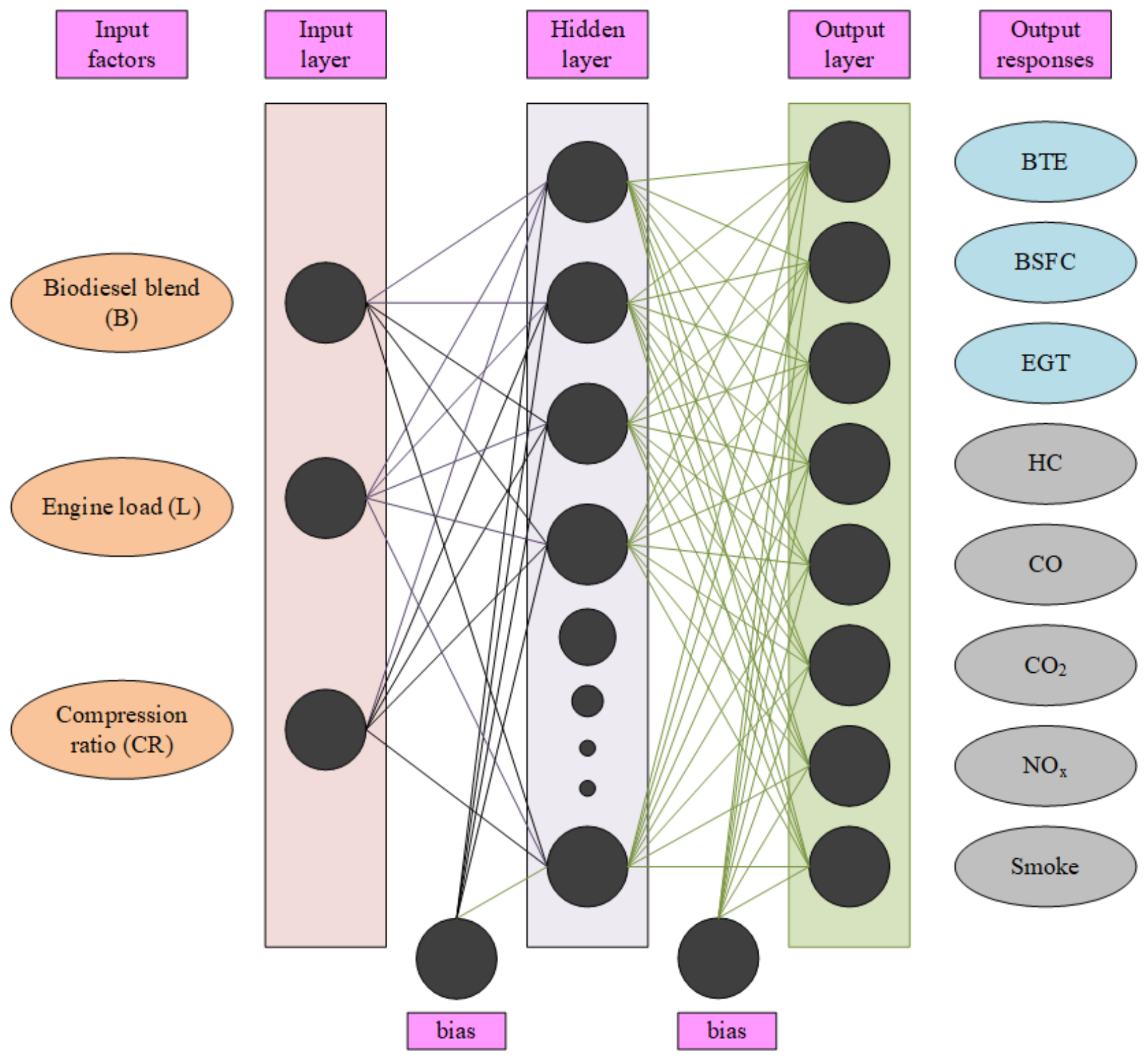

Figure 15

ANN model algorithm on MATLAB 


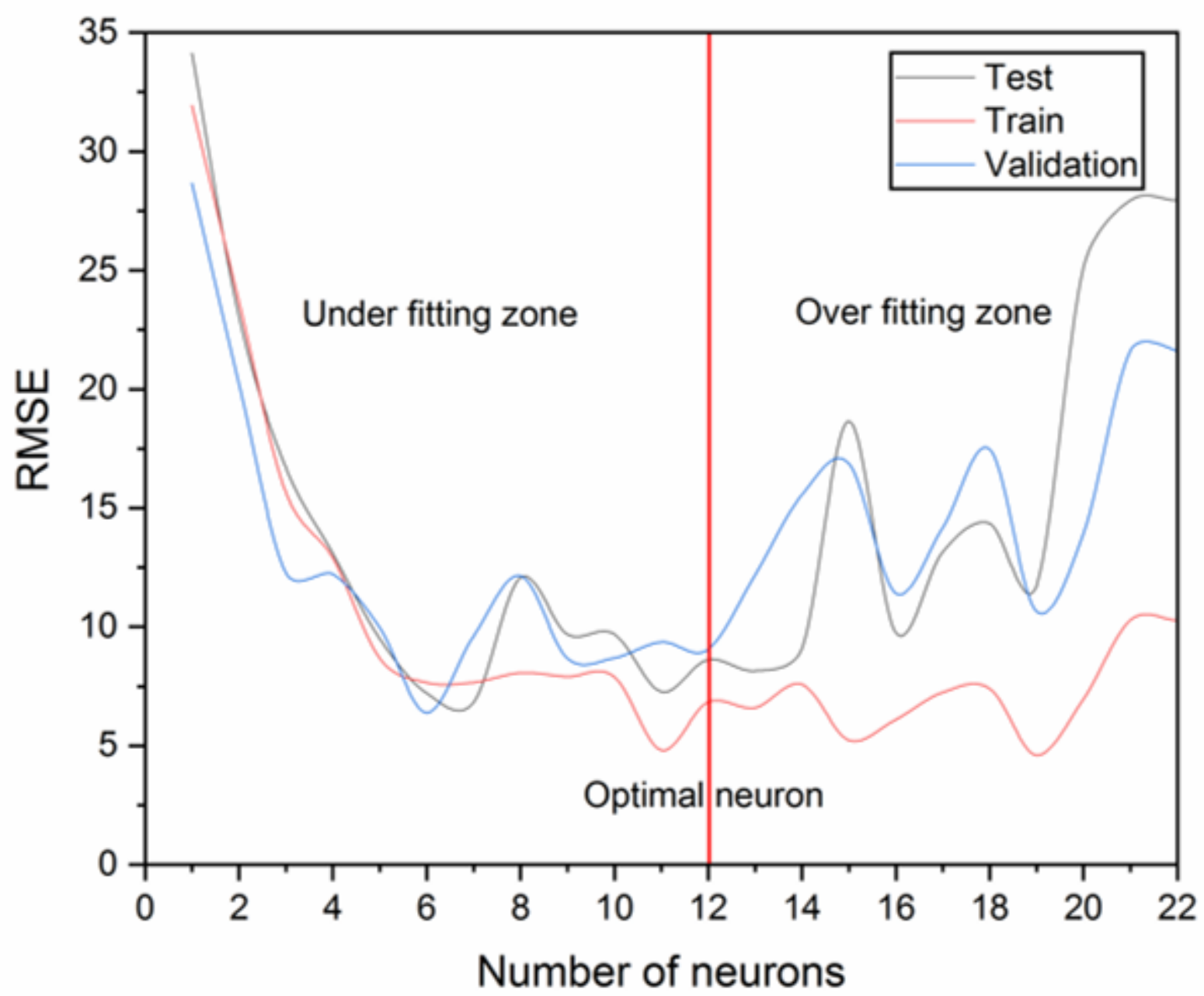

Figure 16

Relationship between the number of neurons and RMSE for selected ANN model 

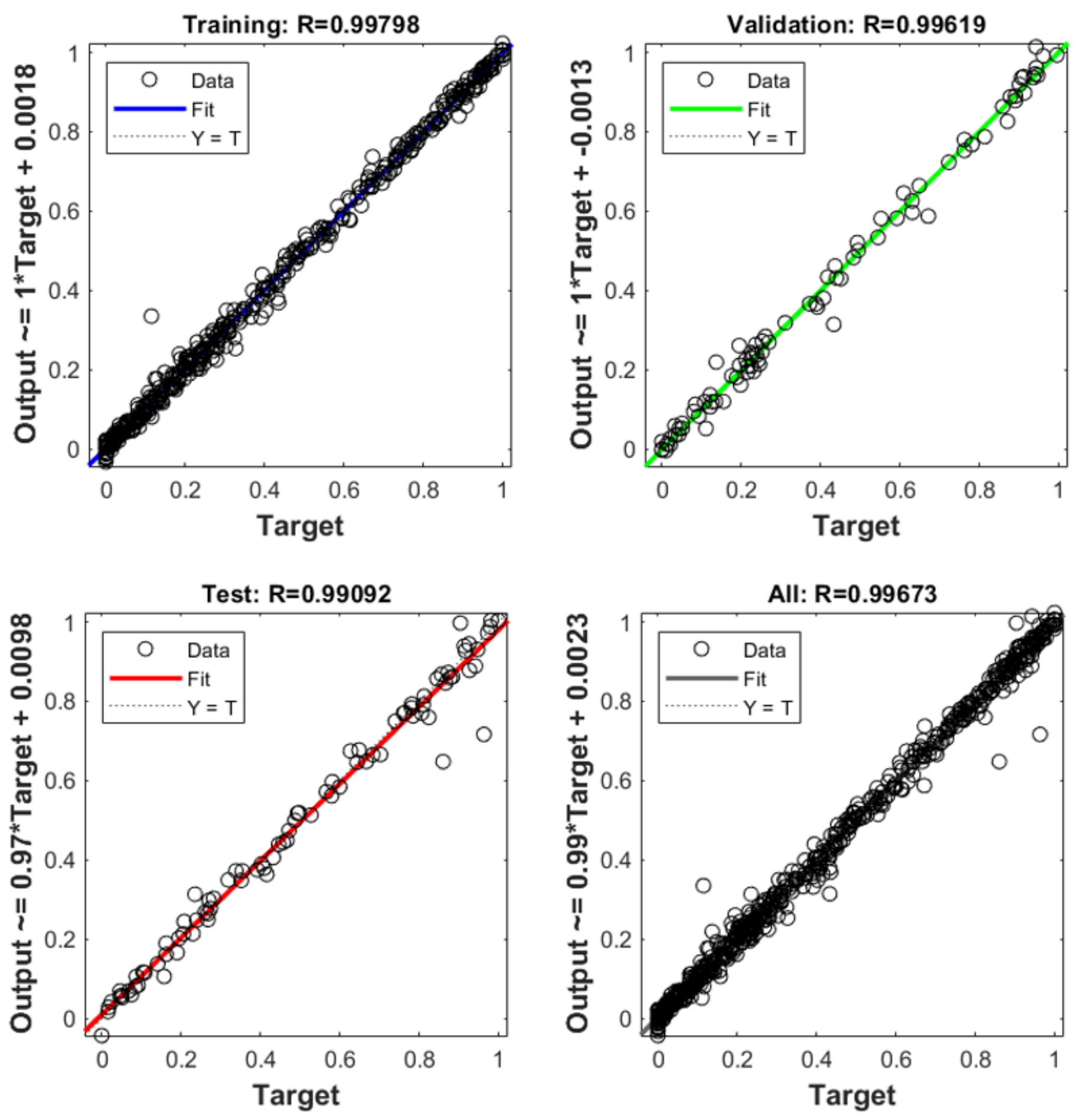

Figure 17

Multiple regression plots for training, validation and test sets 

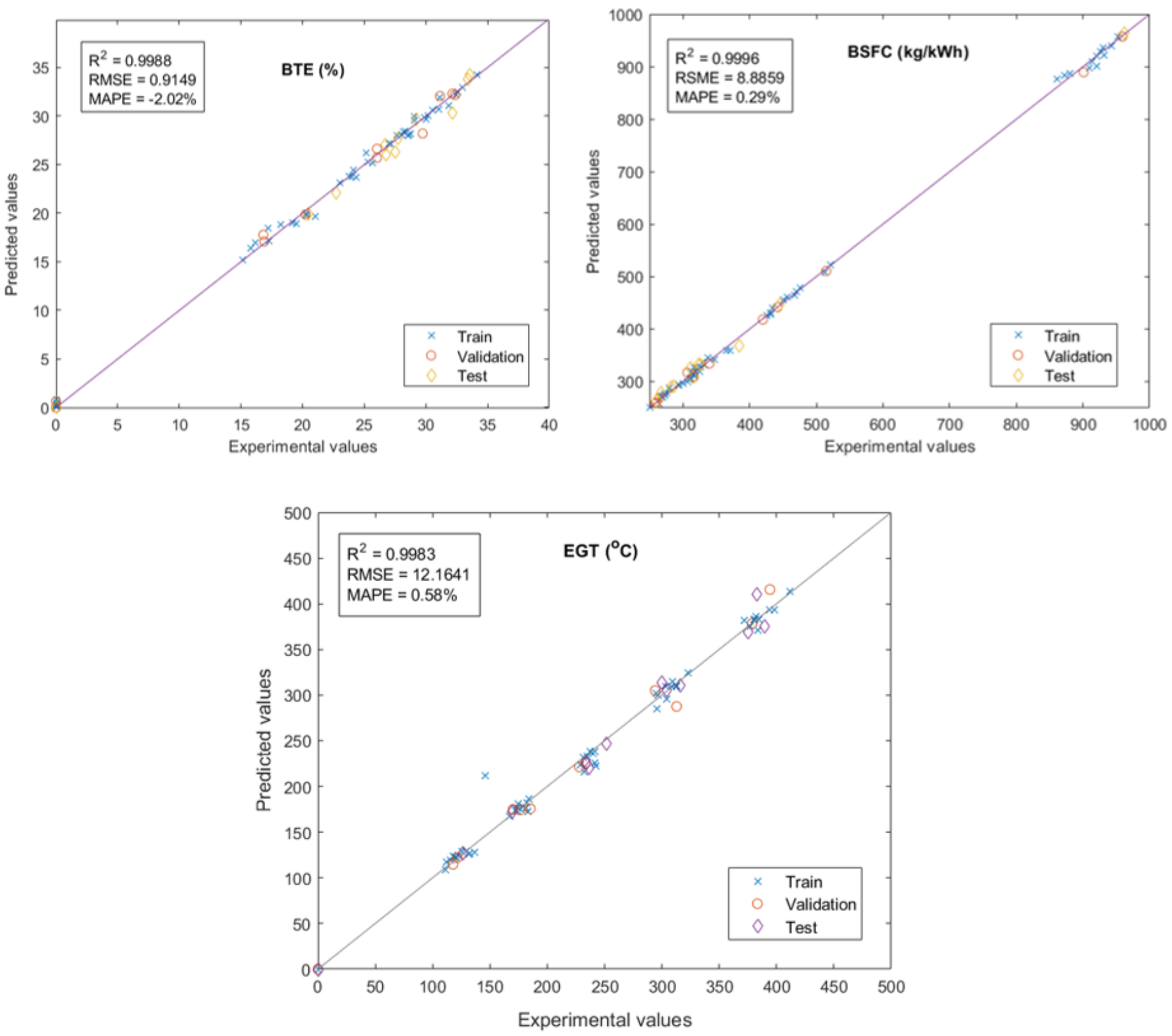

Figure 18

Relationship between experimental vs ANN predicted values for engine performance parameters 

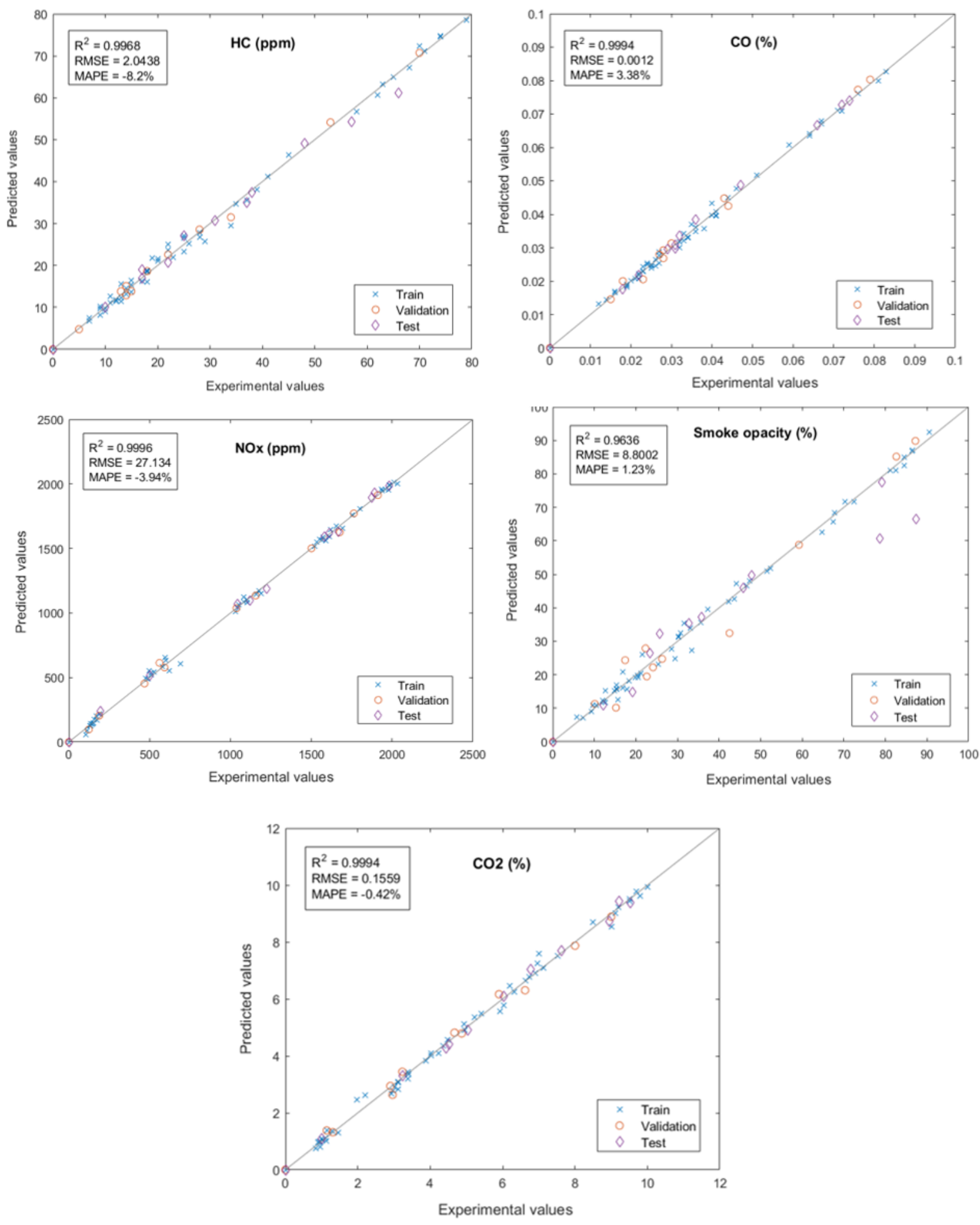

Figure 19

Relationship between experimental vs ANN predicted values for engine emission parameters 